\title{
Access to justice in international courts for indigent states, persons and peoples
}

\author{
Gbenga Oduntan (i)
}

Published online: 4 April 2019

(C) The Author(s) 2019

\begin{abstract}
Funding and litigation finance is an important aspect of international adjudication. The growing literature on courts and tribunal has however overlooked the subject of litigation cost and finance. This paper considers the development of the practice of trust funds that aid access to international courts and tribunals for states as well as corporate and natural persons. Next, the paper addresses strategies to increase access to justice by poorer developing states and indigent persons. The paper evaluates the means by which further confidence in the adoption of international adjudication, arbitral routes and other appropriate dispute resolution routes may be promoted among poorer parties in order to reduce the deleterious effects of acute financial inequalities between litigants and other participants. In order to exhaustively deal with this issue of litigation financing the paper will, therefore, compare the relevant law and processes of the International Court of Justice, the Permanent Court of Arbitration, the International Tribunal for the Law of the Sea, the European Court of Human Rights, the various International Criminal tribunals, the World Trade Organisation and the International Centre for Settlement of Investment Dispute.
\end{abstract}

Keywords Legal aid - International courts - ICJ · PCA · ICSID - Dispute settlement

I presented this article at the W G Hart Legal Workshop on the theme of Access to Justice in 2007. I am grateful to Judith Resnik, Yale Law School, Dane Ratliff, Former Legal Counsel, Permanent Court of Arbitration and Philippe Gautier, Former Registrar of ITLOS for their support, encouragement and guidance.

Gbenga Oduntan (

Kent Law School, Canterbury, Kent, UK

e-mail: O.T.Oduntan@kent.ac.uk

Gbenga Oduntan

Barrister and Solicitor of the Supreme Court of Nigeria, Abuja, Nigeria 


\section{Introduction}

The Permanent Court of Arbitration (PCA) was the first world body, a club of arbitrators, dedicated to the pacific settlement of disputes. It has been about a century and two decades since its establishment in $1899 .{ }^{1}$ International courts and tribunals have since proliferated performing significant functions in the resolution of international disputes. ${ }^{2}$ International Courts including the International Court of Justice (the ICJ or World Court), which is the principal judicial organ of the United Nations continue to perform meritoriously in their important task as peacemakers and dispensers of international justice. ${ }^{3}$ Since the faltering beginnings in the acceptance of the ICJ's jurisdiction there has been an upward spike in its use by states. Perhaps more significantly there is also a dialectical development in the practice of international courts and tribunals. The new, mostly developing, states granted independence from the 1940s onwards have sought third-party resolution of international disputes leading to rise in the popularity of the international courts and tribunals. ${ }^{4}$

The record of developing states in complying with the judgments of arbitral and judicial institutions is commendable. The cost of appearing before international courts however remain formidable for poorer states

${ }^{1}$ PCA cases, Conventions, Rules of Procedure, UNCITRAL Rules and Procedures, and other PCA Rules and Procedures are available online at $<\mathrm{http}$ ///www.pca-cpa.org/ENGLISH/BD/ $>$. For a discussion, see, PS Rao, Multiple International Judicial Forums: A Reflection of the Growing Strength of International Law or its Fragmentation? 25 Mich J Intl L (2004) 929. VS Mani, International Adjudication: Procedural Aspects (M. Nijhoff, Laiden, 1980).

${ }^{2}$ For accounts of the historical origins and early inspiration of arbitration and adjudication see Isaiah Chapter 2:4. The Bible; Shabtai Rosenne, The World Court: What it is and How it Works (AW Sijthoff- Oceana, New York, 1973)11-12; IG Tenekides, International Law and Federal Communities in the Cities of Greece, 90 R.A.D.I. (1956) 469. For literature on the development of the ICJ and PCA see D.J. Bederman, The Hague Peace Conferences of 1899 and 1907, in, M Janis (ed) International Courts for The Twenty-first Century (M Nijhoff Publishers, Leiden, 1992) 9; G Schwarzenberger, Present-day relevance of the Hague Peace System, 1899-1979, 34 Yrbk World Aff (1980) 329; RK Gardiner, International Law (Pearson Longman, London, 2003) 473; JW Wheeler \& M Fanshawe, Information on the World Court 1918-1928 (Allen Unwin, London, 1929) 6.

3 The Charter of the UN and the Statute of the Court entered into force on 24 October 1945. After the election of its members on 6 February 1946, the World Court met for the first time in The Hague on 1 April of the same year. The first case entered in the General List of the Court, Corfu Channel, United Kingdom v. Albania, was submitted on 22 May 1947. Materials on all ICJ cases are available online at <http://www.icjcij.org>.

${ }^{4}$ As a writer puts it 'dispute resolution has never been so popular'. A Paulus, International Adjudication, in, Samantha Besson \& John Tasioulas (eds) The Philosophy of International Law (OUP, Oxford, 2010) 207. See also JG Merrils, International Dispute Settlement, 5th edn (CUP, Cambridge, 2011) x, 307-309. The Project on International Courts and Tribunals (PICT) established in 1997, lists up to 125 international dispute settlement bodies. About 12 of these are judicial bodies in the narrow sense. See, <http://www.pict-pcti. org/publications/synoptic_chart/synop_c4.pdf>. 
as well as other indigent persons, both natural and corporate. ${ }^{5}$ There are two issues:

First, there are natural upward hike in the cost of using these venerable institutions as well as costs of legal representation and other experts. Secondly, with worsening economic fortunes of many developing states, especially those affected by the global recession, disposable income available to governments for use in qualitative pursuance of international claims or to even defend foreign actions may have considerably reduced.

These socio-economic realities are compounded by an upsurge in international disputes as a result of phenomenal increases in global trade, international business transactions, globalisation, massive growth of human settlements and populations. Other factors like nationalism, irredentism, religious fundamentalism, terrorism as well as other vicissitudes of international politics have also contributed to the increase in international disputes. It is easily predictable that the 21st century would witness further rises in conflicts that require resolution by international processes. It is important, therefore, to ensure that the costs of appearing before international tribunals and/or the costs of implementing judgments and awards should be kept within reasonable bounds. At any rate it is important to consider existing and emerging strategies and mechanisms by which the cost of justice can be ameliorated in order not to deter states from the practice of international courts. This paper, therefore:

(a) considers the development of the practice of trust funds that aid access to international courts for states as well as corporate and natural persons;

(b) identifies the leading schemes through which international justice has been financially subsidised for judicial and quasi-judicial bodies;

(c) addresses strategies to increase access to justice by poorer, developing states and indigent persons;

(d) evaluates the means by which further confidence in the adoption of international adjudication, arbitral routes and other appropriate dispute

\footnotetext{
5 Enforcement by performance of international decisions have been typical in the case of most states and indeed some of the most egregious cases of non-enforcement or disobedience to international decisions has been by the developed states or by connivance with them. A case in point will be the fate of the final judgment against the U.S. in the case Military and Paramilitary Activities in and Against Nicaragua (Nicaragua. v. U.S.) [1986] ICJ 14, 23. Attempts to seise the Security Council of jurisdiction towards enforcement were vetoed by the U.S. thereby rendering the judgment unenforceable. See U.N. Docs. S/18250 (1986) and S/PV. 2704 (1986). SG Ogbodo, An Overview of the Challenges Facing the International Court of Justice in the 21st Century, 18 Annual Survey Intl \& Comp Law (2012) 18.
} 
resolution routes may be promoted among poorer parties, in order to reduce the deleterious effects of acute financial inequalities between litigants and other participants;

(e) compares and contrast the existing major international legal aid schemes;

(f) explores ideas on better ways to structure the various existing legal aid schemes in order to protect indigent states and persons.

The paper will thereafter, compare the relevant law and processes of the following types of international dispute resolution bodies:

- mainly public international law enforcing bodies: including the ICJ, the Permanent Court of Arbitration; ${ }^{6}$ the International Tribunal for the Law of the Sea (ITLOS) ${ }^{7}$; The European Court of Human Rights (ECtHR); ${ }^{8}$

- The erstwhile international criminal tribunals: namely (International Criminal Tribunals for former Yugoslavia (ICTY) ${ }^{9}$ The International Criminal Tribunal for Rwanda (ICTR) ${ }^{10}$ and the existing International Criminal Court (ICC). ${ }^{11}$

- The mainly economic and commercial international tribunals: the World Trade Organisation; The International Centre for Settlement of Investment Dispute.

- The Internal Tribunal of International Organisations (namely the Office of Staff Legal Assistance).

References will also be made to other national and international courts and arbitral bodies for illustrative purposes. The thesis to be tested is whether there continues to exist, a problem of access to justice affecting poorer states and peoples. With the available schemes in place can we safely arrive at the conclusion that there is an emerging right under customary international law in favour of indigent states, peoples and persons who may lack adequate access to litigate or appear before

\footnotetext{
${ }^{6}$ The PCA cases, Conventions, Rules of Procedure $<$ https://pca-cpa.org/en/home/ $>$.

7 ITLOS cases, Conventions, Rules of Procedure <http://www.itlos.org/>.

${ }^{8}$ Information about the ECtHR <www.echr.coe.int $>$.

9 The ICTY is now defunct since 2017 but Information about the ICTY is available on its memorial, $<$ http://www.icty.org/>.

${ }^{10}$ The ICTR is now defunct and was wound up on 31 December 2015. The tribunal was governed by its Statute, which is annexed to Security Council Resolution 955. The Rules of Procedure and Evidence, which the Judges adopted in accordance with Article 14 of the Statute, established the necessary framework for the functioning of the judicial system. ICTR cases, Conventions, Rules of Procedure, $<$ http://www.un.org/ictr/ $>$.

${ }^{11}<$ www.icc-cpi.int>.
} 
international courts due to shortage of funds to receive help through workable schemes designed to ameliorate this problem in the international system. The significance of such a study lies in the reduction of scope for injustice in the international system as a result of high costs of appearing before international courts and tribunals.

Section 2 sets out the general issue of the problem of cost in international adjudication. Section 3 offers insights into the history of the scheme of aid and funding in international adjudication. Various subsections of Section 3 look into the International Court of Justice (the ICJ), the Permanent Court of Arbitrations (PCA) and the International Tribunals for the Law of the Sea (ITLOS). Section 4 discusses funding, cost and financial aid in international criminal adjudication. Sections 5 and 6 discuss human rights litigation, litigation at the World Trade Organization (WTO) and the International Centre for Settlement of Investment Dispute (ICSID). Section 7 provides an overarching critique and analysis of the preceeding discussions relating to the available funding schemes before the general conclusions in Section 9.

\section{The problem of costs: fiscal implications of international litigation and arbitration}

Just as in the municipal setting where the financially well to do find it easier to institute civil action to address their grievances or weaponize the courts against others in civil and criminal cases, so also in the society of nations those with better financial resources appear to have a better chance at seeking to sway the hands of justice. ${ }^{12}$ Richer litigants typically get better and more expensive representation ${ }^{13}$ and deploy better expert witnesses. ${ }^{14}$

\footnotetext{
${ }^{12}$ It is reported that in the United States, billionaire private actors have been clandestinely funding other people's lawsuits in an attempt to censor the press or any other perceived threats to their wellbeing. See NK Chipi, Eat Your Vitamins and Say Your Prayers: Bollea v. Gawker, Revenge Litigation Funding, and the Fate of the Fourth Estate, 72 Univ Miami L Rev (2017) 269; L Levi, The Weaponized Lawsuit Against the Media: Litigation Funding as a New Threat to Journalism, 66 Am U LRev (2017) 761, 785. See, also, Chris Hanretty, Haves and Have-Nots before the Law Lords, Political Studies (2013) 686-697.

${ }^{13}$ O Bowcott, Appeal court judge 'horrified' at number of litigants without lawyers, The Guardian (Sunday 23 November 2014) <https://www.theguardian.com/law/2014/nov/23/appeal-court-judgehorrified-number-litigants-without-lawyers $>$.

${ }^{14}$ Rich litigants will be able to deploy expert witness and to better effect than poorer ones. As Irvin Younger explains 'Rich litigants can retain an expert. A poor litigant will not be able to retain an expert because he does not have the money and because he is actively forbidden to retain the expert on a contingent basis. ...The common law, however, has said that an expert witness is in a very different position. The expert witness has an opinion. The common law traditionally regards the expert witness' opinion as his private property'. I Younger, A Practical Approach to the Use of Expert Testimony, 31 Cleveland State L Rev (1982) 1, 9.
} 
This paper outlines three categories of costs. First are primary and direct costs such as payments due for instituting the proceedings and/or defence of the cases. This would include the cost of representation on behalf of the state or peoples involved as well as costs for the use of physical facilities and personnel of the requisite court. Second, there are indirect costs such as costs of travel, case preparation, evidence gathering, lodging, feeding and welfare. Third, there are costs relating to implementation. The most obvious of this is the payment of judgment sums where applicable. However, such costs may extend nearly infinitely to collateral events.

Examples to illustrate will include the costs for further processes of discovery, repatriation of funds or artefacts, further directed processes (Alternative Dispute Resolution), surveys, cartography development, delimitation and demarcation. Thus, costs can doubtless be a factor deterring many developing states from making use of international courts. Whenever an individual appears before an international criminal court or as an applicant before a human rights court, the financial costs are potentially quite high. ${ }^{15}$ It is, therefore, the case that some states cannot litigate for financial reasons. For as Castaneda rightly noted of litigation before the ICJ, it makes little difference whether the case is a contentious suit or one requiring an advisory opinion, the costs are considerable and frequently too high. ${ }^{16}$

Litigation at the ICJ, depending on the nature of the dispute may require several millions of dollars even before the cost of implementation are considered. In many cases the cost of implementation will be several times the cost of litigation. Maritime boundary litigation for instance, involves exceptionally high open and hidden costs. There would usually be the need for experts on geography, cartography, oceanography, geologists, and other specialists in addition to costs for exhibits, memorials and lawyers.

Land boundary demarcation may also be equally prohibitive. Acquisition of satellite imagery, ground surveys, mapping and erection of boundary pillars would normally require immense sums to accomplish. In many cases both land and maritime issues are at stake

\footnotetext{
${ }^{15} \mathrm{DH}$ Anderson, Trust Funds in International Litigation, in, N Ando, E McWhinney \& R Wolfrum (eds) Liber Amicorum Judge Shigeru Oda (Kluwer Law International, Leiden, 2002) 793-794; P Bekker, International Legal Aid in Practice: The ICJ Trust Fund, 87 Am J Intl L (1993) 659. CC Okolie, International Law Perspectives of Developing Countries: The Relationship of Law and Economic Development to Basic Human Rights (MOK Publishers, Lagos, 1978) 50-51.

${ }^{16}$ Max Planck Institute, Judicial Settlement of International Disputes: An International Symposium. (Max Planck Institute, New York, 1974) 30.
} 
from litigation through to implementation. Even for wealthy nations there is the problem of competing priorities and considerations of opportunity cost. ${ }^{17}$ The implications are certainly even direr for developing states. For countries like these it is impossible not to agree with Sir Arthur Watts that the best form of help is not just words of support and encouragement, it is money'. ${ }^{18}$

The administrative cost of instituting proceedings at an international court is just the beginning of a series of serious expenditure. Ironically, in comparison to the hidden financial cost of litigation the administrative fees appear modest. For instance, with respect to the PCA a nonrefundable registration fee of 2000 Euro is accruable to the institution to secure the processes of commencement of proceedings. ${ }^{19}$ However, the cost of the services of each key staff can go up to as much as 250 Euro per hour. Several Registry staff may be needed at a time and the hours to be paid for may run into thousands of hours. This of course does not include the cost of use of facilities and the remuneration of arbitrators.

In international arbitrations it is usual that each party to a commercial dispute pay for the arbitrator(s) they nominate whereas the cost of the presiding arbitrator/umpire will be shared between the parties. Since the average PCA case lasts many years it becomes clear then that this will have a further negative effect on the costs of proceedings before this court. For poorer developing states, the risk of defeat might carry far greater financial weight especially since throughout the history of the institution 'there was always a winner and a loser' in all legal encounters. ${ }^{20}$ It needs therefore, be said that the problem of costs needs urgent attention, especially as these costs are on the increase.

One of the reasons why the issue of costs of international justice must attract sustained attention in legal literature and in international studies is that often the onset of international crises is typically unavoidable and unpredictable. Furthermore, the situations that give rise to them occur quite rapidly and inexplicably giving little options to the requirement

\footnotetext{
17 The Australian government, for instance, has on many occasions resorted to US law firms to advise it on matters relating to litigation before the WTO as a result of a dearth of home-grown expertise. Australia has also resorted to US firms where there was a need to research into domestic law aspects of the US domestic sugar program and to prepare the Lamb Meat case. Department of Foreign Affairs and Trade, 'Australia's Relationship with the World Trade Organization (WTO): Submission to the Joint Standing Committee on Treaties by the Department of Foreign Affairs and Trade'. September 2000, at $58<$ http:// www.dfat.gov.au/trade/negotiations/wto/aust_wto.pdf $>$.

18 Statement by Sir Arthur UN Doc. A/44/PV.43 (1989) 13.

19 The Schedule of Fees of the PCA including the fees structure for guest tribunals that use the PCA facilities are available at the PCA website. See, <https://pca-cpa.org/fees-and-costs/>.

20 Max Planck Institute, supra note 17 at 30.
} 
that parties have to rise to the occasion without fail. Reference may be made here to the recent and increasing practice of prosecution of individuals before international criminal courts and the appearance of individuals before international human rights courts.

In these cases, two separate considerations of costs may arise. First, there is the view of the individuals that appear before the court. This in turn may be divided further into the costs that face the accused person(s) or human rights applicant. Secondly, accruable expenses against witnesses, amici curie and other persons that attend the trial at their own expense.

In the usual cases, an international criminal court which requires the attendance of witnesses, experts and other persons would bear the cost of their attendance. But in the nature of things and as a result of the highly emotive incident of international criminal trials, certain interests need to also be recognised if not actively protected. This includes victims of the accused persons who may want to attend the trials or make an appearance or make statements before the court without being summoned. This was certainly the case after the Rwandan genocide and the Yugoslavia war and their attendant international criminal tribunals which we treat below.

Even for states, the imperative to make an appearance may be unavoidable and may occur at an economically inopportune time. It is not too difficult to envisage that states emerging from a civil or international war may not have enough funds to engage meaningfully in an international criminal trial. The state may be in dire financial straits when it has to help maintain or finance an international trial.

Outside criminal cases, there are poorer states that often find themselves repeatedly brought within the jurisdiction of international courts for high profile investment and commercial disputes. Clearly therefore, there is a problem of costs of international justice worthy of attention by lawyers and practitioners of international relations. Certain general principles of financial liability in international organisations may be deduced at this stage and we will highlight five such issues here:

Firstly, the expenses of the principal international courts and arbitral tribunals are defrayed not from fees paid by parties for cases but rather from a regular institutional budget to which the member States contribute. In accordance with Article 33 of the ICJ statute for instance, the expenses of the Court shall be borne by the United Nations. This only covers administrative costs. In the case of the PCA, pursuant to 
Article 50 of its 1907 Convention the expenses of its Bureau are borne by the Contracting Powers in the proportion fixed for the International Bureau of the Universal Postal Union. ${ }^{21}$

Secondly, the normal rule before international courts and tribunals is that each party bears its own costs, irrespective of the outcome. Article 64 of the Statute of the International Court of Justice reads: 'Unless otherwise decided by the Court, each party shall bear its own costs.' The same rule appears as Article 34 of the ITLOS Statute. Exceptions are very rare in inter-State litigation before courts and tribunals of many types.

Thirdly, the cost of defence of an individual before an International Criminal Court is borne by the individual unless he or she cannot bear this cost wholly or in part and there is a scheme attached to the court to which some or all of the expense may be defrayed.

Fourthly, the cost of bringing claims before an international human rights court is borne by the complainant/applicant unless he or she cannot bear this cost wholly or in part and there is a scheme attached to the court or some other body to which some or all of the expense may be defrayed.

Fifthly, the provision of aid to states and persons may also take the form of donation of expertise (lawyers, technocrats, scientists, historians, ethnographers) and other reasonable contributions in kind. In the usual instance such donations would be desired and accepted by the state(s) concerned.

\section{The legal aid scheme for international courts and tribunals}

In 1945 the Charter of the UN brought into being a new judicial organ now known as the ICJ. The ICJ Statute is annexed to the Charter of which it forms an integral part. The first fifty years of the Court's life was characterised by a relatively poor number of appearances by developing States. Many reasons have been adduced by observers of the Court for this. ${ }^{22}$ It was thought that a major reason for the poor turn out at the Court is that some states cannot just afford the rising cost of justice.

\footnotetext{
${ }^{21}$ Constitution, General Regulations: Resolutions and decisions Rules of procedure Legal status of the UPU with commentary by the International Bureau of the UPU (International Bureau of the Universal Postal Union, Berne, 2005).

22 For some of these reasons see the discussions of problems of the Court in G Oduntan, Law and Practice of the International Court of Justice a Critique of the Contentious and Advisory Jurisdictions (Michigan State Univ Press, Michigan, 1999).
} 


\section{A. The 1989 Trust Fund of the ICJ}

The Secretary-General of the UN in 1989 announced the creation of a legal aid scheme to financially assist developing states in litigating before the ICJ. ${ }^{23}$ The non-aligned states majority of which are "indigent states" sensibly pushed through the agenda for the creation of a trust fund in order to enhance the use of the Court by member States. ${ }^{24}$ The Trust Fund idea might also have been inspired by Switzerland's commendable $\$ 400,000$ assistance to Burkina Faso and Mali to help them implement the ICJ boundary decision in the Frontier Dispute case. ${ }^{25}$ In the final analysis, however it was the UN Secretary General, Senor Javier Perez de Cuellar who took the initiative in 1989 to create the Trust Fund. ${ }^{26}$

The existence of this fund has received much praise in literature and it has transformed into a fund that is not only available for the use of litigants before the Court but one which allows for the completion of the adjudicatory process by also funding judgment implementation activities. Requests for assistance from the fund are to be referred to a panel of experts who advise the Secretary-General. ${ }^{27}$ The object of the fund is to provide 'financial assistance to States for expenses incurred in connection with (i) a dispute submitted to the International Court of

${ }^{23}$ UN Doc. A/44/PV.43, at 7-11 (1989). This was based upon a directive of the U.N. General Assembly. See Provisional Verbatim Record of the Forty-Third Meeting, 44 UN GAOR (43rd Mtg.) at 7-11 UN Doc./ 44/PV.43 (1989).

24 The many accounts of where the greatest impetus for the introduction of the various legal aid schemes came from attest to the success of the idea. Many states, writers and jurists have been known to jostle for primacy of position in the chronology of the creation of the schemes. Ministerial Meeting of Non-Aligned Countries, U.N. Doc. A/44/PV.59, at 2 (1989); the Hague Declaration of the Meeting of the Ministers of Foreign Affairs of the Movement of Non-Aligned Countries to discuss the Issue of Peace and the Rule of Law in International Affairs, U.N. Doc. A/44/191 (1989); Bien-Aime, Enhancing the Role of the World Court: An Examination of the Secretary-General's Trust Fund Proposal, 22 NYU J Int'l L \& Practice (1991) 671.

${ }^{25}$ Burkina Faso v. Mali [1987] ICJ Rep 7 (Nomination of Experts, Order of 9 April 1987). The dispute was so contentious that an outbreak of military hostilities ensued during the case. However, when the court ruled, the two States found they could not afford the cartographers needed to actually turn the Court's decision into a useable map. Switzerland's financial help supplied the needed experts. See, M Ellen O'Connell, International Legal Aid: The Secretary-General's Trust Fund to Assist States in the Settlement of Disputes through the International Court of Justice, in, Mark W. Janis (ed) International Courts for the Twentyfirst Century (M Nijhoff, Leiden, 1992) 235.

${ }^{26}$ On the occasion of the consideration of the Report of the Court 1989, the Secretary-General announced the initiative to the General Assembly, referring to his responsibility to promote the settlement of disputes by the Court. In a very rare move whereupon there was no proposal, debate or decision in the General Assembly, the Secretary-General established by his own motion a permanent Trust Fund with its own terms of reference. Annex to United Nations Document A/47/444 of 7 October 1992. See, 28 ILM (1989) 1589.

27 An annual report on the fund is made to the General Assembly, and the Secretary-General may revise the Terms of Reference, Guidelines and Rules if circumstances so require. See Terms of Reference Guidelines and Rules of the Secretary-General's Trust Fund to Assist States in the Settlement of Disputes through the International Court of Justice, 28 ILM 1590, Para. 171989 [hereinafter, Terms of Reference]. 
Justice by way of a special agreement, or (ii) the execution of a judgment of the Court resulting from such special agreement. ${ }^{, 28}$

The Terms of Reference specify that the Fund will be financed out of voluntary contributions from states as well as contributions from corporations, foundations and organisations with legal interests etc. ${ }^{29}$ In order to receive funds, a state must submit cost estimates for specified expenses involved in the suit. The experts will then consider the expenses and issue funds along with a budget. In return, the requesting state must make an undertaking to submit receipts in a manner consistent with the stringent U.N. audit system. ${ }^{30}$

Over the last few decades available funds have stuck stubbornly below the 3 million dollar mark and the use of the funds have been quite sparring arguably as it should be. Financial assistance to the tone of 700000 dollars was awarded in equal halves to Benin and Niger in $2004 .^{31}$ In 2009 , available funds rose to $\$ 2,687,770.61$. This amount excludes awards that have already been paid. ${ }^{32}$ By 30 June 2012, the last year the ICJ provided a comprehensive report on its scheme, the Fund's balance, net of awards already paid, was $\$ 2,959,966.39 .^{33}$

\section{B. The Financial Assistance Fund of the PCA}

The PCA, established by treaty in 1899 , is one of the foremost intergovernmental organizations based at The Hague and it provides a variety of dispute resolution services to the international community. There was no widely agreed formalisation of international arbitration procedure until the Hague Conventions of 1899 and $1907 .{ }^{34}$ These two conventions gave the definition of Arbitration as 'the settlement of disputes between states by judges of their choice and on the basis of

${ }^{28}$ Ibid.

${ }^{29}$ Ibid. [7].

${ }^{30}$ Ibid. [8(ii]) and Financial Regulations and Rules of the U.N., ST/SGB/Fin. Rules 1/Rev.3 3 (1985).

${ }^{31}$ Fifty-ninth session Agenda item 13 Report of the International Court of Justice Secretary-General's Trust Fund to Assist States in the Settlement of Disputes through the International Court of Justice, UNGA, United Nations A/59/372.

${ }^{32}$ See, Report of the International Court of Justice Secretary-General's Trust Fund to Assist States in the Settlement of Disputes through the International Court of Justice, Sixty-fourth session Item 74 of the provisional agenda, United Nations A/64/308 at $2<$ http://daccessdds.un.org/doc/UNDOC/GEN/N09/ 485/90/PDF/N0948590.pdf?OpenElement>.

${ }^{33}$ Sixty-seventh session, Agenda item 71 Report of the International Court of Justice Secretary-General's Trust Fund to Assist States in the Settlement of Disputes through the International Court of Justice Report of the Secretary-General, A/67/494 <https://documents-dds-ny.un.org/doc/UNDOC/GEN/N12/529/90/ PDF/N1252990.pdf?OpenElement>.

${ }^{34}$ The 1907 Convention had the same name as its predecessor UKTS 6 (1971), Cmnd. 4575. 82 parties. The Convention revised the 1899 Convention in light of the Courts experience in its early cases. 
respect for law.' The PCA as created by the Second Hague Conference held in 1907, existed throughout the era of the League of Nations and up till today. It suffered a period of relative inactivity for fifty years but the number of cases it handles has been rising steadily. After nearly a century, of typically handling only one or two cases at a time, it has gradually experienced an increase in business. ${ }^{35}$ Currently the PCA is acting as registry in 4 inter-state proceedings, 84 investor-state arbitrations, and handles 46 cases under contracts involving a state or other public entity. ${ }^{36}$

The expectation is that several more cases will be brought before this important body. Arbitral business is assured by the high number of subscriptions to its jurisdiction by Contracting Powers to one or both of the Conventions of 1899 and $1907 .{ }^{37}$

The PCA presently occupies a unique juncture between public and private international law from which it could meet the rapidly evolving dispute resolution needs of the international community. Under its modern rules of procedure, which are based upon the highly regarded and widely used UNCITRAL Arbitration Rules, the PCA administers arbitration, conciliation and fact finding in disputes involving various combinations of states, private parties and intergovernmental organizations. Not only do states more frequently seek recourse to the PCA, but international commercial arbitration can also be conducted under PCA auspices. Whereas Article 47 of the 1907 Convention aims at a universal relevance for the PCA problems of access to this court appear to persist. The aforementioned provision states:

With the object of facilitating an immediate recourse to arbitration for international differences, which it has not been possible to settle by diplomacy, the Contracting Powers undertake to maintain the Permanent Court of Arbitration, as established by the First Peace Conference, accessible at all times. ${ }^{38}$

\footnotetext{
${ }^{35}$ See Report of the Secretary General CA/42.810 March 72003 Some of the major attempts made to revitalise the PCA include the 1962 PCA Rules of Arbitration and Conciliation for the Settlement of International Disputes Between Two Parties of which Only One is a State, first used in Sudan/Turriff Construction Ltd., (1970). The 1993 Optional Rules for Arbitrating Disputes between Two Parties of Which Only One Is a State replaced these Rules. See, JG Wetter, The International Arbitral Process, vol. V (Oceana Publications, NY, 1979) at 187. See, Redfern \& Hunter, Law and Practice of International Commercial Arbitration (Sweet and Maxwell, London, 1999) 58, 170; PCA cases, Conventions, Rules of Procedure, UNCITRAL Rules and Procedures, and other PCA Rules and Procedures <http://www.pca-cpa.org/ENGLISH/BD/>.

${ }^{36}$ A list of cases in which the parties have agreed to release public information and past cases are available at $<$ https://pca-cpa.org/en/cases/>.

371899 Convention for the Pacific Settlement of International Disputes and the 1907 Convention for the Pacific Settlement of International Disputes. Apart from the PCA Arbitration Rules there are the PCA Mediation/Conciliation Rules the PCA Fact-finding Commissions of Inquiry Rules and the PCA Founding Conventions and Internal Rules.

38 UNGA Official Records, 21st Session Item 66 Provisional Agenda.
} 
Without prejudice to the many achievements of the PCA in its 117 years of existence it is possible to argue that its record in relation to poorer and indigent states and peoples needs more improvement. Africa, for instance, has been far less a customer of this court than probably it ought to be. Of the 53 Existing states in Africa today only 16 of them are parties to the PCA. This may or may not serve as an indicator as to the popularity of the PCA in Africa (depending on who is examining the situation) but it does fit with the theory that poorer states and the businesses that are indigenous to them may be faced with certain peculiar challenges which largely prevent them from frequent appearance before international courts. In this way they may have become somewhat disenfranchised from the international arbitral process both in international commercial arbitration and in public international law with clear consequences on the development of international law. ${ }^{39}$

It is with this background that much satisfaction is derived from the fact that in October 1994, the Administrative Council agreed to establish a Financial Assistance Fund and approved the Terms of Reference and Guidelines for the operation of the Fund. This Fund, to which contributions are made on a voluntary basis, provides financial assistance to qualifying states to enable them to meet, in whole or in part, the costs involved in international arbitration or other means of dispute settlement offered by the Hague Conventions. Qualifying states are state parties to the Conventions of 1899 or 1907 that:

(1) have concluded an agreement for the purpose of submitting one or more disputes, whether existing or future, for settlement by any of the means administered by the PCA; and (2) at the time of requesting financial assistance from the fund, are listed on the "DAC List of Aid Recipients" prepared by the Organization for Economic Co-operation and Development (OECD). A qualifying state may seek financial assistance from the fund by submitting a written request to the Secretary-General of the PCA. An independent Board of Trustees decides on the request. ${ }^{40}$

\footnotetext{
39 These themes have been explored by the author elsewhere. See, G Oduntan, How International Courts Underdeveloped International Law: Economic, Political and Structural Failings of International Adjudication in Relation to Developing States, 1 African J Intl \& Comp L (2005) 262-313.

40 The Terms of Reference and Guidelines of this Fund allows a "Qualifying State" to seek financial assistance in order to meet, in whole or in part, expenses for the Settlement of International Disputes (the "Fund). Such a state must at the time of requesting financial assistance from the Fund be listed on the "DAC List of Aid Recipients" prepared by the Organization for Economic Co-operation and Development (OECD). The DAC List of ODA Recipients effective as at 1 January 2015 for reporting on 2014, 2015 and 2016 flows remain in effect another year to cover 2017 flows, following the DAC's decision to remove the retroactive date of effect of decisions on graduation from the list. The List which will govern ODA flows in 2018, 2019 and 2020 is available at <http://www.oecd.org/dac/financing-sustainable-development/development-financestandards/daclist.htm $>$.
} 
Since the establishment of the fund, Norway, Cyprus, the United Kingdom, South Africa, the Netherlands, and Costa Rica have made contributions, and four grants of assistance have been made: one to a Central Asian state, one to an Asian state, and two to African states. These grants have allowed the parties to defray the costs of arbitration. ${ }^{41}$ It is noteworthy that virtually all the 16 African states signatory and parties to the Hague Conventions of 1899 and 1907 are found on this DAC list, which includes 52 African States and Territories.

It should be realised that according to Article 10 of the Terms of Reference much less may be given to the recipient state than is requested, and any terms and conditions deemed appropriate may be attached to it. With the Financial Assistance Fund, it may be noted that although developing states must continue to contribute to the purse of the PCA, the problem they face in terms of accessibility to the court may have been reduced as a result of the scheme. ${ }^{42}$ This is significant because the rising cost of justice is but one of the many problems developing states face in the search for international justice.

\section{ITLOS Trust Fund}

ITLOS is an independent judicial body established by the United Nations Convention on the Law of the Sea to adjudicate disputes arising out of the interpretation and application of the Convention. ${ }^{43}$ The Tribunal is composed of 21 independent members, elected from among persons enjoying the highest reputation for fairness and integrity and of recognized competence in the field of the law of the sea. Pursuant to the provisions of its Statute, the Tribunal has implemented several Chambers - viz: the Chamber of Summary Procedure, the Chamber for Fisheries Disputes, the Chamber for Marine Environment

\footnotetext{
${ }^{41}$ See PCA Annual Report (2005) $7<$ https://pca-cpa.org/en/about/annual-reports/>.

42 For instance, according to the Budget of the PCA for the Biennium 2004-2005 the following amounts in Euro was assessed in Annual Contributions for the 16 African states in each year. Burkina Faso (659.00); Cameroon (1,318.00); Dem Rep of Congo (3,954.00); Egypt (6 590.00); Libya (6,590.00); Mauritius (1,318.00); Morocco (1,318.00); Nigeria (13, 180.00); Senegal (1,318.00); South Africa (13,180.00); Sudan (659.00); Swaziland (1,318.00); Uganda (659.00) Zambia (1,318.00); Zimbabwe (3,954.00).

43 The Tribunal came into existence following the entry into force of the Convention on 16 November 1994. The first judges were elected on 1 August 1996 and ITLOS began its work in Hamburg on 1 October 1996 although the official inauguration of the Tribunal was held on 18 October 1996. Cases submitted to this important tribunal include: cases arising out of the application or interpretation of the United Nations Convention on the Law of the Sea. Such matters are the prompt release of vessels and crews under article 292 of the Convention, coastal State jurisdiction in its maritime zones, freedom of navigation, hot pursuit, marine environment, flags of convenience and conservation of fish stocks'. Agreements between states may also confer jurisdiction on the Tribunal. Information and materials about ITLOS. See, $<$ https://www.itlos. org/general-information/>.
} 
Disputes and the Chamber for Maritime Delimitation Disputes. ${ }^{44}$ Twenty-five cases have been submitted to the Tribunal as at 2018 .

In the year 2000 the General Assembly concluded its consideration of an agenda item titled 'Oceans and the law of the sea' and adopted inter alia Resolution 55/7.45 This resolution requested the establishment and administration of a Trust Fund to assist parties in the settlement of disputes through the Tribunal. The purpose of the Trust Fund is to provide financial assistance in appropriate cases to parties to a dispute before the Tribunal.

The ostensible aim of the various delegations of the General assembly in seeking the creation of the fund was to increase access to the Tribunal for developing States. The fund maintained by the Division for Ocean Affairs and the Law of the Sea (DOALOS) of the United Nations Office of Legal Affairs, helps developing states to cover the costs related to lawyers' fees or travel and accommodation of their delegation during the oral proceedings in Hamburg.

A panel of independent experts reviews applications made by parties and make recommendations to the Secretary-General of the United Nations on the amount of financial assistance to be given. States, international organizations, non-governmental organizations, as well as natural and juridical persons are continually invited to make financial contributions to the fund. ${ }^{46}$

ITLOS as a service is not cheap to maintain. The budget of the Tribunal for 2017-2018 was EUR 21,119,900. ${ }^{47}$ The expenses of the Tribunal are borne by the States Parties to the Convention and there is no cost for parties submitting cases by or on behalf of States Parties to the Tribunal. ${ }^{48}$ Non-States Parties however, would be required to pay a fee fixed by the Tribunal.

The trust fund was first used in the Juno Trader case about prompt release which was delivered on 18 December 2004. In 2005, an amount of $\$ 20,000$ was awarded to Guinea-Bissau. Contributions to this

\footnotetext{
44 ITLOS Yrbk (M Nijhoff Publishers, Leiden, 2008) <http://www.itlos.org/start2_en.html>.

45 Fifty-fifth session Agenda item 34, Resolution adopted by the General Assembly [without reference to a Main Committee (A/55/L.10 and Corr.1 and Add.1)]. 55/7. Oceans and the law of the sea. <https://www. itlos.org/fileadmin/itlos/documents/basic_texts/trust_fund_terms_eng.pdf $>$.

46 Judge P Chandrasekhara Rao, President of the Tribunal Addresses Millennium General Assembly Trust Fund to Provide Assistance to Parties to Dispute - ITLOS/Press 39 (14 November 2000) <http:// www.itlos.org/start2_en.html accessed $>$.

47 The annual budget of the Tribunal is set and adopted by the Meeting of States Parties to the Convention, on the basis of budget proposals submitted by the Tribunal. See ITLOS, General Information, $<$ https://www.itlos.org/general-information/>.

48 First Five Years of the International Tribunal for the Law of the Sea, ITLOS/Press $58(2001)<$ https:// www.itlos.org/fileadmin/itlos/documents/press_releases_english/PR_No.58.pdf $>$.
} 
Tribunal's fund is also quite slow and quite insufficient if consideration is taken of the potentially expensive nature of resolution of maritime disputes. The United Kingdom was the first to contribute to the fund when it donated US\$24,865 into its coffers. ${ }^{49}$ In the year 2006 a total of contribution of $\$ 12,724$ was put into the coffers from only one state, Finland. At end of that year the fund had a balance of $\$ 85,869$. There was, however, no expenditure in the whole of 2006 and the fund stood at $\$ 70,621.17 .^{50}$ This is one of the trust funds to which the General Assembly has repeatedly urged States to contribute. ${ }^{51}$

\section{Trust Funds for Financial Assistance towards Internship Programmes}

Aside from the Trust Fund which assists state parties, two further trust funds that are worthy of mention here have been instituted since 2010 . Their specific goal is to facilitate attendance of internship programmes of ITLOS for candidates from the developing world. A 'Trust Fund for the Law of the Sea' was established in $2010 .{ }^{52}$ This fund quickly attracted two contributions in April 2010 and October 2011. The first $(€ 25,000)$ was made by Korwind, a Hamburg-based Korean company, and the second by the Korea Maritime Institute (KMI). In May 2012 a new trust fund was set up with financial support from the China Institute of International Relations (CIIS). ${ }^{53}$

These two funds were preceded by the special grants established by the Korea International Cooperation Agency in 2004, which enabled 11 interns in 2004, 14 in 2006, nine in 2009 and seven in 2010 to benefit

\footnotetext{
49 Statement by P Chandrasekhara Rao President of the ITLOS on The Report of the Tribunal at the Twelfth Meeting of the UNCLOS States Parties (16 April 2002) <https://www.itlos.org/fileadmin/itlos/ documents/statements_of_president/chandrasekhara_rao/msp_160402_eng.pdf $>$.

${ }^{50}$ Report of the UN Secretary-General on the Oceans and the law of the sea, Doc A/62/66 (12 March 2007) [358]. Statement by Mr. Rüdiger Wolfrum, President of The International Tribunal For The Law Of The Sea On Agenda Item 71 (A) At The Plenary Of The Sixty-First Session Of The United Nations General Assembly (8 December 2006).

51 See for instance General Assembly resolution Sixty-first session Agenda item 71 (a)

06-50769 Resolution adopted by the General Assembly on 20 December 2006 [without reference to a Main Committee (A/61/L.30 and Add.1)] 61/222.

52 President Jesus Addresses United Nations General Assembly Press Release / Press 155 (8 December 2010) 1 <https://www.itlos.org/fileadmin/itlos/documents/press_releases_english/pr_155_eng.pdf > .

53 ITLOS, Internship Programme, <https://www.itlos.org/the-registry/training/internship-programme/?\% C2\%B4\%27\%270x27=8cHash=a3fd42682860776cad0bc677eaede $>$ at 348; Statement By H.E. Judge Jose Luis Jesus President Of The International Tribunal For The Law Of The Sea On Agenda Item 74 (A) "Oceans And The Law Of The Sea” At The Plenary Of The Sixty-Fifth Session Of The United Nations General Assembly (7 December 2010); ITLOS, The Twenty-Second Meeting Of States Parties To The 1982 United Nations Convention On The Law Of The Sea Celebrates The 30th Anniversary of the Opening for Signature of the Convention Press Release / Press 177 (12 June 2012).
} 
from participation in the Tribunal's internship programme. These grants cover the interns' expenses during their participation in the programme. ${ }^{54}$ In the nature of things both funds have quite limited available resources. In addition to the standard requirements for participation in the ITLOS internship programme, the following criteria apply in determining eligibility for internship funding:

(a) applicants must be nationals of a developing country included in the OECD list and should normally be resident in that country; and

(b) applicants should need financial assistance to help cover the travel and living costs associated with an internship in Hamburg.

\section{Funds for various International Criminal Courts and Human Rights Courts}

\section{A. The ICC}

The International Criminal Court (ICC) based at The Hague, is an intergovernmental organization and international judicial tribunal which began functioning on 1 July 2002, under the Rome Statute - a multilateral treaty. ${ }^{55}$ The ICC investigates and, where warranted, tries persons charged with the gravest crimes of concern to the international community such as genocide, war crimes, crimes against humanity and the crime of aggression. The ICC was created to complement existing national judicial systems and it may therefore, only exercise its jurisdiction when certain conditions are met, such as when national courts are unwilling or unable to prosecute criminals or when the

${ }^{54}$ Statement by Mr L. Dolliver M. Nelson, President of the International Tribunal For The Law of the Sea On Agenda Item 49 (A) At The Plenary Of The Fifty-Ninth Session Of The United Nations General Assembly (17 November 2004); Statement By José Luis Jesus President of the International Tribunal for The Law of the Sea on the Report of The Tribunal at The Twentieth Meeting of States Parties to the UNCLOS (14 June 2010) 8 <https://www.itlos.org/fileadmin/itlos/documents/statements_of_president/jesus/msp_ 140610_eng.pd>.

55 Rome Statute of the International Criminal Court <https://www.icc-cpi.int/NR/rdonlyres/ ADD16852-AEE9-4757-ABE7-9CDC7CF02886/283503/RomeStatutEng1.pdf $>$. The Court's first legal aid policy was instituted following a process that commenced in January 2003 involving direct consultation with over 50 experts comprising: the Court's external partners, the legal profession and ad hoc tribunals, etc. In addition, Court officials undertook exploratory missions to national bars which have in place well established domestic legal aid systems. See the International Criminal Court, Registry's single policy document on the Court's legal aid system, ICC-ASP/12/3 Assembly of States Parties 4 June 2013 Twelfth session The Hague, (20-28 November 2013) <https://asp.icc-cpi.int/iccdocs/asp_docs/ASP12/ICC-ASP-12-3-ENG.pdf>. 
United Nations Security Council or individual states refer situations to the Court.

It is important to note that states generally have an obligation to cooperate in investigations and legal proceedings under Article 86 of the Rome Statute. Furthermore, the ICC benefits from a genuine power of leadership in the trial, enabling the Court to request the cooperation of states. In essence any discussion of legal aid only relates to aiding indigent accused persons and/or indigent victims. As would be expected the costs of running an important institution like this will be substantial and the Courts current budget for 2018 is $€ 147,431,500$. The ICC as an institution aims to ensure the effectiveness of the rights of the defence. It is envisaged that costs must not be the reason why a robust defence should be unattainable. Thus, the Rome Statute of the ICC provides in article 67 , that the accused has significant rights which include:

$[T]$ o be present at the trial, to conduct the defence in person or through legal assistance of the accused's choosing, to be informed, if the accused does not have legal assistance, of this right and to have legal assistance assigned by the Court in any case where the interests of justice so require, and without payment if the accused lacks sufficient means to pay for it.

The legal aid scheme of the court is contained in the ICC Legal Aid Policy. The policy contains the relevant resolutions adopted by the Assembly on the question of legal aid as listed, the applicable legal provisions governing legal aid as stipulated in the Court's legal instruments as well as the internal Registry guidelines and standard operating procedures including the ICC Rules of Procedure and Evidence (RPE). The journey to the implementation of the policy was long and chequered a fact which has helped to produce the robust system that is currently in place.

The ICC Legal Aid System is impressive in comparison with those of the other courts treated so far but it obviously has its own share of criticisms as well. Its legal aid budget for the defence in 2016 was $€ 4,521,000.3$. This is an increase from $€ 2,866,400$ in 2014 , and $€ 2,355,600$ in 2015 . However, in relative terms to the overall budget of the organisation the 2016 budget represents only $3.25 \%$ of the total ICC budget. Indeed, over the last five years it has averaged a mere $2 \%$ ). It has always been less than $10 \%$ of the budget allocated to the Office of the Prosecutor (OTP). ${ }^{56}$

In essence the ICC's Legal Aid System and the policy backing it are struggling to balance the requirements for adequate, effective and

\footnotetext{
${ }^{56}$ RJ Rogers, Assessment of the ICC's Legal Aid System (Global Diligence LLP, London, 2017) 9, 10.
} 
efficient legal representation of indigent clients with the budgetary constraints of a publicly funded legal aid scheme. The system covers the costs of legal representation of indigent persons - those who lack sufficient means, in part or in whole to assume such costs - and ensures that indigent beneficiaries receive adequate resources to cover 'all costs reasonably necessary as determined by the Registrar for an effective and efficient' legal representation as stipulated in regulation 83 of the Rules of the Court'.

There are certain operative and objective principles used to determine the need for aid including obligations to dependants, flexibility and simplicity. Principles underlying the appraisal of indigence include the following:

1. objective criteria for calculating both the means at the disposal of the person requesting payment of legal assistance by the Court and the scale of admissible expenses, thereby reducing, if not avoiding, the risk of error in the financial assessments;

2. ability to continue providing for obligations to dependants. To this effect, a financial information form is included in the standard form for legal aid applications and contains several slots in which the occupation, salary and other sources of income of dependants must be stated. This allows the Registry to calculate the amount of the obligations owed to them, if any, by the person requesting the payment of legal assistance from the Court. ${ }^{57}$

3. compliance with the requirements of fairness with the system. This is of course flexible, allowing account to be taken of any changes in the financial status of the person and his or her dependants;

4. finally, avoidance of excessive complexity by enabling the Registry to present a simple yet comprehensive mechanism that is compatible with the above criteria. ${ }^{58}$

\footnotetext{
57 The financial information form is designed to enable a person seeking legal aid to properly inform the Registry of the income and assets at his or her own disposal and at the disposal of the persons living in his or her household. The purpose of this declaration is to commit the person claiming indigence to full cooperation with the Registry in the financial investigation process. The information is usually checked by the financial investigator in order to properly assess the application for legal aid and to avoid undue use of legal aid funds.

${ }_{58}$ Report on the operation of the court's legal aid system and proposals for its amendments, No. ICCASP/6/4 (31 May 2007) [26] (hereinafter Adjustment Report). Regulations of the court No. ICC-BD/01-03-11, adopted by the judges of the court on 26 May 2004, regulation 85(1) and also Regulations of the Registry No. ICC-BD/03-01-06-rev.1, date of entry into force, 6 March 2006, regulation 132 of the Regulations of the Registry.
} 
It is noteworthy that the ICC system on application of legal aid considered and made provisions for frivolous, malicious or fraudulent obtainment of legal aid. Indeed in accordance with rule 21(5) of the RPE, '[if the] where a person claims to have insufficient means to pay for legal assistance and this is subsequently found not to be so, the Chamber dealing with the case at that time may make an order to recover the cost of providing counsel.' These are very progressive and supportable provisions. Clearly schemes on international legal aid should not be drawn up in a way to encourage or permit deliberate or inordinate wastage.

\section{B. Trust Funds for Victims (TFV) of the International Criminal Court}

The TFV represents the second flank in the battle against indigence as an impediment to genuine access to international criminal justice via the ICC. The TFV was created as an independent body by the Rome Statute and established by the Assembly of States Parties to complement the work of the ICC. It focuses on reparations for victims of the terrible crimes that fall under its jurisdiction (such as genocide, crimes against humanity and war crimes). The TFV is empowered to use the contributions it receives to finance projects for the benefit of victims and their families. ${ }^{59}$

In the ICC, victims have the right to participate in all stages of the proceedings by putting their views and concerns to the judges. If a case proceeds to trial and the accused person is convicted, victims may ask the court to make an order of reparations for the harm they have suffered. The judges may thus, order individual or collective reparations. The type of reparations will also be decided by the judges and may include compensation, restitution, rehabilitation and symbolic measures such as public apology or a commemoration or memorial. Victims' participation in proceedings is entirely different from a victim's possible role as a witness called to testify before the court for the prosecution or the defence.

In northern Uganda alone in a decade of assistance the fund has provided medical rehabilitation, psychological rehabilitation, and livelihood support. It is projected that more than 45,000 people have directly

\footnotetext{
59 Director of the Trust Fund met with victims' communities in Uganda Kampala (13 June $2007<$ http:// www.icc-cpi.int/press/pressreleases/252.html>.
} 
benefitted from the programme. Indirect beneficiaries are estimated at about 200,000 people, who benefit either as family or community members. ${ }^{60}$

C. Legal Aid of the International Criminal Tribunals for former Yugoslavia

The ICTY was established as a result of Security Council resolution 827 passed on 25 May 1993. Serious violations of international humanitarian law had been committed in the territory of the former Yugoslavia since 1991 , and the tribunal was a response to the threat to international peace and security posed by those serious violations. It was established by the United Nations as a court of law to deal with war crimes that took place during the conflicts in the Balkans in the 1990's. From its inceptions in 1993 it was quite quickly and widely regarded as a game changer which irreversibly changed the landscape of international humanitarian law. It among other things, provided victims an opportunity to voice the horrors they witnessed and experienced under the forensic atmosphere of a civilised criminal trial.

In this way the Tribunal has undoubtedly laid the foundations for individual accountability as the accepted norm for conflict resolution and post-conflict development across the globe. Specifically, it has laid down the template that in these modern times leaders that are suspected of mass crimes will face justice. Persons that were indicted at the ICTY include a head of state, prime minister, army chiefs-of-staff, interior ministers and many other high- and mid-level political, military and police leaders from various parties to the Yugoslav conflicts. Its indictments address crimes committed from 1991 to 2001 against members of various ethnic groups in Croatia, Bosnia and Herzegovina, Serbia, Kosovo and the Former Yugoslav Republic of Macedonia. ${ }^{61}$

As at 2017 when the ICTY completed its tasks, a total of 90 individuals had been convicted out of a total number of 161 indicted

\footnotetext{
${ }^{60}$ Commemorating the 20th anniversary of the Rome Statute, the President of the Assembly of States Parties to the ICC, 10 States Parties, and the Trust Fund for Victims conclude a joint programme monitoring visit to Uganda <https://www.trustfundforvictims.org/sites/default/files/inline-files/Press\%20release\% 20Ireland-TFV\%20joint\%20programme\%20monitoring\%20visit\%20UGA\%20-22Feb2018.pdf>.

${ }^{61}$ See, General Assembly- Security Council, General Assembly Sixty-fourth Session Item 76 of the provisional agenda, Report of the International Tribunal for the Prosecution of Persons Responsible for Serious Violations of International Humanitarian Law Committed in the Territory of the Former Yugoslavia since 1991 United Nations A/64/205-S/2009/394, 31 July 2009 <http://www.icty.org/sections/ AbouttheICTY>.
} 
persons. 19 persons were acquitted of their cases while 37 cases were withdrawn and 13 were referred to national courts. ${ }^{62}$

The expense of bringing to justice those most responsible for war crimes and for helping to cement the rule of law in the former Yugoslavia pales in comparison to the true cost of the crimes: the lives lost, the communities devastated, the private property ransacked and the cultural monuments and buildings destroyed forever. ${ }^{63}$ Thus, aside from its impressive addition to the jurisprudence of reconciliation of the tensions between human rights and armed conflict, the legal aid scheme of the ICTY represented an investment in the peace and future of south-eastern Europe. ${ }^{64}$

The operation of its legal aid programme for indigent defendants fell under the purview of the ICTY Registry's judicial responsibilities along with tasks such as the organisation of hearings, legal filings and archives, the provision of assistance and protection to witnesses, and the management of the Detention Unit. As a result of the immense responsibilities foisted upon this important institution provision of funding was a key issue throughout its existence. To begin with the Tribunal's budget covered activities that would not ordinarily be undertaken by a court in a national system, such as the running and management of its Detention Unit; the legal aid system; the witness protection and assistance programme; the translation of documents and simultaneous interpretation of proceedings; organisation of travel of investigators to collect evidence and interview witnesses; and the provision of security of evidence, buildings and staff among many other functions.

The Registry was charged with the task of determination of the eligibility of an accused person for legal aid in accordance with Article 8 of the Directive and the 'Registry Policy for Determining the Extent to which a Suspect or an Accused is able to Remunerate Counsel' (Registry Policy). Article $8(\mathrm{~B})$ of the Directive and the detailed information of what may be included and excluded in the applicant's disposable income is contained in The Registry Policy for Determining the Extent to Which an Accused Is Able to Remunerate Counsel. ${ }^{65}$

\footnotetext{
${ }^{62}$ Infographic: ICTY Facts \& Figures, <http://www.icty.org/en/ content/infographic-icty-facts-figures $>$.

${ }^{63}$ ICTY, Bringing Justice to the Former Yugoslavia the Tribunal's Core Achievements $<$ http://www.un. org/icty/latest-e/index.htm>.

${ }^{64}$ P Akhavan, Reconciling Crimes Against Humanity with the Laws of War: Human Rights, Armed Conflict, and the Limits of Progressive Jurisprudence, 6 J Intl Criminal Justice (2008) 21-37.

65 Entered into force from 4 May 2004.
} 
The Registry's policy was to first determine the disposable means of an applicant for legal aid. From this a deduction is made of the disposable means available to such persons including the estimated living expenses of his family and dependents during the estimated period in which the applicant will require representation before the ICTY. The amount remaining will thus, constitute the contribution to be made by the applicant to the costs of his defence.

Following this formula, it was decided in the decision of the ICTY in Prosecutor v. Momcilo Perisic case ${ }^{66}$ that in accordance with Article 11(A)(ii) of the Directive, the accused person was partially eligible for legal aid and that he ought to contribute US\$97,125 to the costs of his defence. Detailed information of what may be included and excluded in the applicant's disposable income is contained in The Registry Policy for 'Determining the Extent to Which an Accused is Able to Remunerate Counsel' which Entered into force from 4 May 2004. The Registrar in fact had occasion to withdraw legal aid from a defendant on the basis that, the defendant had acquired sufficient means to pay for the cost of his defence for the remainder of his appeal against conviction. ${ }^{67}$

According to the erstwhile President of the Court, a Registrar's decision to permit or deny assignment of counsel based on the "interest of justice" exception involves questions of both fact and law: and the Registrar must first make certain factual determinations, either about the circumstances of the defendant's case or, as in this case, about the counsel in question's past conduct, or about both. Given the facts as he finds them, he must then determine the matter in accordance with the overriding consideration of 'interests of justice'. The Registrar's task was therefore, 'an administrative fact-finding procedure' and 'need only be established as more probable than not'. ${ }^{68}$

It may thus, be concluded that the eligibility of an accused for legal aid was determined by considering 'means of all kinds of which he has direct or indirect enjoyment or freely disposes, including but not limited to direct income, bank accounts, real or personal property, pensions, and stocks, bonds, or other assets held, but excluding any family or social benefits to which he may be entitled.' In assessing such means,

\footnotetext{
66 No. IT-04-81 PT.

67 The Prosecutor v. Miroslav Kvocka et al. - Case No. IT-98-30/1-A (7 February 2003), Judges Shahabuddeen (Presiding), Hunt, Gunëy, Gunawardana and Meron. See International Criminal Court, Decision on Review of Registrar's Decision to Withdraw Legal Aid from Zoran Zigic <https://www.icc-cpi.int/>.

68 The Prosecutor v. Veselin Sljivancanin - Case No. IT-95-13/1-PT 'Decision on Assignment of Counsel' (20 August 2003) Judge Theodor Meron, President, Ibid.
} 
account was always taken of the means of the spouse of a suspect or accused, as well as those of other persons with whom he habitually resides. Account may indeed also have been taken of the apparent lifestyle of a suspect or accused, and of his enjoyment of any property, movable or immovable, whether or not he derives income from it. The principles that guided the Registry of the ICTY were quite robust and commendable. It is recommended that these criteria will be useful for determination of legal aid in relation to future international criminal courts.

\section{Legal Aid Program of the International Criminal Tribunal for Rwanda}

The ICTR was established for the prosecution of persons responsible for genocide and other serious violations of international humanitarian law committed in the territory of Rwanda between 1 January 1994 and 31 December 1994. The ICTR is now defunct but is still useful to our analysis as evidence of international practice useful in developing further the law and practice of international legal aid. It had the power to deal with the prosecution of Rwandan citizens responsible for genocide and other such violations of international law committed in the territory of neighbouring States during the same period. ${ }^{69}$

Security Council Res. 955 (1994) adopted at its 3453rd meeting on 8 November 1994, had urged all States and intergovernmental and nongovernmental organizations to contribute funds, equipment and services to the International Tribunal, including the offer of expert personnel. ${ }^{70}$ The Statute of the ICTR (annexed to Res. 955) in article 20 (4) (d) expressly provided for the right of suspects:

To be tried in his or her presence, and to defend himself or herself in person or through legal assistance of his or her own choosing; to be informed, if he or she does not have legal assistance, of this right; and to have legal assistance assigned to him or her, in any case where the interests of justice so require, and without

\footnotetext{
69 In the life of its existence prior to its winding up on 31 December 2015, ICTR indicted 93 Individuals for genocide and other serious violations of international humanitarian law committed in 1994. It concluded proceedings for 85 accused persons and made 5 transfers to other jurisdictions (Rwanda (3) and France (2)). 23 persons were transferred to another State to serve their sentences. 10 are awaiting transfer to other States to serve their sentence. 23 have indeed served their sentence while 6 in fact died before or while serving their sentence ( 2 died before judgement). 14 accused persons were acquitted and released, 2 indictments were withdrawn. See further, P Akhavan, The International Criminal Tribunal for Rwanda: The politics and pragmatics of punishment, 90 Am J Intl L (1996) 501-503.

70 Security Council, Doc No: Distr.GENERAL S/RES/955 (1994) <http://www.unmict.org/specials/ ictr-remembers/docs/res955-1994_en.pdf?q=ictr-remembers/docs/res955-1994_en.pdf>.
} 
payment by him or her in any such case if he or she does not have sufficient means to pay for it.

The UN kept budgetary control over the ICTR through the United Nations Advisory Committee on Administrative and Budgetary Questions (ACABQ). A Legal Aid Program funded the defence of most of the accused appearing before the Tribunal. In 2004 the UN General Assembly passed Resolution 57/289, which called for managing, monitoring and controlling the expenses of the Legal Aid Program. This particular resolution appeared to have led to a tightening of the purse strings of the legal aid scheme witnessing a situation whereby defence investigators were denied a permanent presence in Arusha (capital of Tanzania) during the life of the presentation of their cases.

Furthermore, there was the implementation of a regressive daily subsistence allowance following a grace period in Arusha. Defence Counsel considered these changes so undesirable and harming of their ability to present their case that the Association of Defence Counsel of the ICTR (ADAD) embarked on a brief strike action. ${ }^{71}$ Indeed the Registrar had expressed serious concern that it would be difficult to expect the ICTR to deliver if it was deprived of the minimum resources necessary. ${ }^{72}$

Funds available under the legal aid scheme of this court were limited and hard fought for. It was thus, not surprising that throughout its existence the pressures of funds was evident in the operations of the court including the application of the available aid. Indeed quite early in the work of the ICTR, a UK Solicitor Mr. Andrew McCartan, was discharged as lead Counsel for a defendant Mr. Joseph Nzirorera after the Tribunal found evidence of inflation of legal bills and other financial irregularities. ${ }^{73}$ The investigation conducted by the Registry revealed evidence supporting, that the Lead Counsel in the particular instance inflated his bills of October and November 2000 and did provide his Legal Assistant with pre-signed blank forms for submission and reimbursement of expenses. It was decided that such behaviour constituted a serious violation of the Code of Professional Conduct for Defence Counsel. ${ }^{74}$

\footnotetext{
${ }^{71}$ External Relations and Strategic Planning Section ICTR, vol. 1, ICTR Newsletter, No. 7 (January 2004) 4 $<$ http://www.icty.org/en>.

${ }^{72}$ External Relations and Strategic Planning Section ICTR, Vol. 1, ICTR Newsletter, No. 5, (October 2003).

${ }^{73}$ United Nations, News: Defence lawyer removed for financial dishonesty, Press Release (6 February 2002) <http:// unictr.unmict.org/en/news/defence-lawyer-removed-financial-dishonesty>.

74 Ibid.
} 
In this way the ICTR Registry displayed impressive vigilance in the administration of the Tribunal's legal aid scheme. By so doing they ensured that high professional and ethical standards were maintained in the defence of persons accused before the ICTR whilst the Tribunal's legal aid system was saved from abuse. The costs of the trials and the difficult nature of the task of the tribunal is well attested to in the following quote:

Some might be tempted to dismiss these achievements as too little given the time and expense. All the accused persons being sought by the Tribunal had fled Rwanda to different corners of the world. Their search, arrest and transfer was, and continues to be a major challenge. Location of witnesses - many of them again living outside Rwanda - arranging their travel to Arusha to appear in court as well as managing their security concerns was and is no easy task. A vast team of officials - judges, attorneys, investigators and other staff had to be put together - drawn from different parts of the world speaking diverse languages, from differing cultures and legal traditions. ... So too were defence counsel. Currently 77 in number drawn from 19 countries and representing all the continents. The Office of the Prosecutor in Arusha has 133 staff members from 40 different nationalities. ${ }^{75}$

On 24 May 2005 the Prosecutor of the ICTR for Rwanda Mr. Hassan Bubacar Jallow announced plans to transfer cases of those already indicted by the International Criminal Tribunal for Rwanda to Kigali. A law on transfer of ICTR cases was passed. ${ }^{76}$ Although the transfer was designed $a b$ initio to include an obligation on Rwanda to establish a witness protection and effective legal aid fund for indigent accused persons, the argument may be made that the plan should have been better prepared for considering the many problems that attend the law and practice of legal aid schemes in many developing states. ${ }^{77}$ The transfer of cases to national jurisdictions was designed as part of a strategy to enable the tribunal complete its tasks by the deadline of $2008 .^{78}$ The ICTR delivered its last trial judgement on 20 December 2012 in the Ngirabatware case. The Tribunal's remaining judicial work now rests solely with the Appeals Chamber which as of October 2014, has only one case left (although this case comprises of six separate appeals) pending before it. ${ }^{79}$

\footnotetext{
${ }^{75}$ HB Jallow, ICTR Experience: Guest Lecture at the University of Lund, Sweden, (31 January 2007) reproduced in External Relations and Strategic Planning Section ICTR, ICTR Newsletter (February 2007 ) 5.

76 Cases were to be transferred by April 2007.

77 See, however, Legal Aid Provision in Tanzania: Improving Access to Justice (Legal \& Human Rights Centre, Dar es Salaam, 2004).

78 External Relations and Strategic Planning Section ICTR, ICTR Newsletter (May 2005) 6.

79 See United Nations Mechanism for International Criminal Tribunals, The ICTR in Brief <http://unictr. unmict.org/en/tribunal>.
} 
E. Legal Aid in Human Rights Courts: The European Court of Human Rights

The idea of legal aid may be said to be central to the European concept of a fair judicial process. This is true of the European Union as a body and also its individual member states. ${ }^{80}$ Article 6 of the European Convention on Human Rights ${ }^{81}$ protects the right of an accused person who has no sufficient means to pay for legal assistance. Legal aid is to be given free to such persons 'when the interests of justice so require'. Note may also be taken of the ECtHR Practice Direction ${ }^{82}$ by which deductions of any sums paid or payable by domestic authorities or by the Council of Europe by way of legal aid will be deducted from any costs and expenses awarded in favour of an applicant to the court.

Further provisions on Legal aid at the ECtHR are contained in the Legal Aid provisions of the Rules of Court (100 to 105). ${ }^{83}$ The President of the Chamber may, either at the request of an applicant or of his or her own motion, grant free legal aid to the applicant where (a) it is necessary for the proper conduct of the case before the Chamber; and (b) the applicant has insufficient means to meet all or part of the costs entailed (Rule 100 and 101). In order to determine whether or not applicants have sufficient means to meet all or part of the costs entailed, they shall be required to complete a form of declaration (certified by home authorities) stating their income, capital assets and any financial commitments in respect of dependants, or any other financial obligations (Rule 102). This process also allows the President of the Chamber to consult with the Contracting party before deciding whether or not to grant legal aid.

The legal aid may be quite generously granted to cover not only representatives' fees but also include travelling and subsistence expenses and other necessary expenses incurred by the applicant or appointed

\footnotetext{
${ }^{80}$ In relation to England and Wales for instance, it is said that 'If a person cannot afford legal representation, this can undermine their right to a fair trial, a right which is protected under Article 6 of the Human Rights Act'. See, Benham v UK (1996) 22 EHRR 293 and Granger v UK (1990) 12 EHRR 469. Although it must be realised that ' $[\mathrm{t}]$ he scope of civil proceedings that are eligible for legal aid has been dramatically affected by recent changes in the legislation'. Liberty, 'Legal Aid' <https: / www.libertyhumanrights.org.uk/ human-rights/justice-and-fair-trials/legal-aid>.

${ }^{81}$ Council of Europe, European Convention for the Protection of Human Rights and Fundamental Freedoms, as amended by Protocols Nos. 11 and 14, 4 November 1950, ETS 5 <http://www.refworld.org/ docid/3ae6b3b04.html>.

${ }^{82}$ Just Satisfaction Claims (Costs and expenses 4 (18)); Issued by the President of the Court in accordance with Rule 32 of the Rules of Court on 28 of March 2007.

${ }^{83}$ Rules of Court <https://echr.coe.int/Documents/Rules_Court_ENG.pdf>.
} 
representative(s) (Rule 103). Where there has been a decision to grant legal aid, the Registrar of the Court is charged with the task of fixing (a) the rate of fees to be paid in accordance with the legal-aid scales in force; (b) the level of expenses to be paid (Rule 104).

The ECtHR is quite frugal with its management of funds for legal aid. The President of the Chamber may, if satisfied that the conditions stated in Rule 101 are no longer fulfilled, revoke or vary a grant of legal aid at any time (Rule 105). In 2005 it left $€ 50,000$ unspent for legal aid. ${ }^{84}$ It may indeed appear quite incongruous that at a time when the court's business experienced an expansion in caseload about a decade ago, it also appears to have been spending proportionately less on legal aid. It was assumed that the Court's expenditure on legal aid would rise steadily in the period 2003 to 2007 . The non-corresponding increase in expenditure on legal aid arguably suggests that the Court is quite strict in its policy in granting legal aid and the sums awarded are perhaps too modest. $^{85}$

From a national point of view legal aid may begin only after The ECtHR's system is kick-started and after completion of an application communicated to the concerned Government. The scheme pays for the cost of the applicant and his/her lawyer's trip to Strasbourg. Eligibility for legal aid in England and Wales now depends on the Legal Services Commission accepting that the applicant would be eligible for legal aid in the country. Where the applicant is not eligible for legal aid, the representing lawyer may agree to represent under a conditional fee agreement, that is, on the basis that they will only get paid if the case is won and get the legal costs paid by the Government.

However, because it is notoriously difficult for an ECtHR application to succeed, lawyers are usually reluctant to take this risk. ${ }^{86}$ Whereas it is a bit of solace to litigants that there is no possibility of them being ordered to pay the Government's legal costs, there is however, still very

\footnotetext{
${ }^{84}$ Council of Europe, European Court of Human Rights - Budget requests for 2005, Rapporteur Group on Administrative and Budgetary Questions GR-AB(2004)24 12 October 2004. Publications and materials on the Council of Europe <www.coe.int $>$.

${ }^{85}$ The court's caseload statistics continue to indicate a steady rise. The number of applications lodged grew by $13 \%$ from 34,500 to 39,000 between 2002 and 2003 . The total number of applications pending in January 2004 was 65,800 . This represents an annual increase of $14 \%$. The number of applications before a decision body grew by $30 \%$ to 38,500 in 2003 .

${ }^{86}$ See, Chris Hanretty, Haves and Have-Nots before the Law Lords, Political Studies (15 May 2013). This is despite the contrary impression created by some press reports. See, J Slack, Europe's war on British Justice: UK loses three out of four human rights cases, damning report reveals, Daily Mail (11 January 2012) <http:// www.dailymail.co.uk/news / article-2085420/Europes-war-British-justice-UK-loses-human-rights-casesdamning-report-reveals.html>.
} 
much in place a formidable cost consideration in attempting access to the ECtHR. It needs be mentioned that there are a number of human rights non-governmental organizations with substantial experience and expertise in bringing or advising on European Court applications. Litigants and their legal representatives also have the option of approaching such civil society organisations for advice or assistance on both the European Convention law and the procedure.

\section{The importance of legal assistance before the World Trade Organisation and investment tribunals}

The opportunity of improved trade opportunities and the promise of sustainable development attracted developing countries (DCs) to the WTO. ${ }^{87}$ The disputes that spring up among member states are typically significant and complex. ${ }^{88}$ The WTO is equipped with a dispute settlement system (DSS) which is crucial to ensuring the system's functionality and equality. ${ }^{89}$ The system created as part of the WTO Agreement during the Uruguay Round embodies the Understanding on Rules and Procedures Governing the Settlement of Disputes, commonly referred to as the Dispute Settlement Understanding (DSU). The DSU, which constitutes part of the WTO Agreement (Annex 2) sets out the procedures and rules that define today's dispute settlement system. It is also the result of the evolution of rules, procedures and practices that have developed over almost half a century under the GATT $1947 .{ }^{90}$

The WTO legal process is still highly costly, and the factor of cost primarily affects poorer developing countries. This has led some writers to theorise that this imbalance discourages developing countries from filing and defending complaints against richer countries. ${ }^{91}$ The effort to

\footnotetext{
87 A Lang, World trade after Neoliberalism (OUP, NY, 2011) 316.

${ }^{88}$ United States - Anti-Dumping and Countervailing Duties on Certain Products and the Use of Facts available in Anti-Dumping and Countervailing Investigations, WT/DS539/5 (22 March 2018).

89 Dispute Settlement Understanding (DSU): The Dispute Settlement Understanding is a legal text containing the rules for dispute settlement in the WTO. This instrument is available at https://www.wto. org/index.htm ; Nhan Nguyen, WTO Accession at Any Cost? Examining the Use of WTO-Plus and WTO Minus Obligations for Least-Developed Country Applicants, 22 Temple Intl \& Comp LJ (2008) 243. L Olson, Incentivizing Access to the WTO’s Dispute System for the Least-Developed Countries: Legal Flaws in Brazil's Upland Cotton Decision, 23 Minn J Intl L (2014) 101.

90 WTO, Introduction to the WTO dispute settlement system, <https://www.wto.org/english/tratop_ e/dispu_e/disp_settlement_cbt_e/c1s2p1_e.htm>.

91 L Johannesson, Supporting Developing Countries in WTO Dispute Settlement, IFN Working Paper No. 1120 (1 February 2016) <https://www.oru.se/contentassets/09c82ced6a484d5b83c8da28223a0967/ johannesson_louise_licuppsats_01022016.pdf $>$.
} 
reduce these costs and increase participation by developing countries, as witnessed the development within the WTO of two important supporting measures. The first is the institution of legal assistance and the second is the law and practice of preferential panel composition. The DSU commendably and specifically addresses access to justice for developing states by granting them special and differential treatment in the form of procedural privileges. ${ }^{92}$ In the first instance, it is true that:

$[\mathrm{M}]$ ultilateral dispute settlement system is itself a particular benefit for developing country and small Members. Such a system, to which all Members have equal access and in which decisions are made on the basis of rules rather than on the basis of economic power, empowers developing countries and smaller economies by placing "the weak" on a more equal footing with 'the strong. ${ }^{93}$

Furthermore, a developing country is given additional or privileged procedures such as longer or accelerated deadlines. The scheme also takes the form of special and differential treatment in consultations; at the panel stage, stage of implementation and during accelerated procedure at the request of a developing country Member (See Decision of 5 April 1966).

\section{A. Specific Legal Assistance: Legal Aid Scheme of the DSU}

The (WTO) Secretariat assists developing countries at their request with legal advice and assistance. To this end, the Secretariat is required to make available a qualified legal expert from the WTO technical cooperation services to any developing country member which makes a requests for additional advice (Article 27.2 of the DSU). According to Art 27.2:

While the Secretariat assists Members in respect of dispute settlement at their request, there may also be a need to provide additional legal advice and assistance in respect of dispute settlement to developing country Members. To this end, the Secretariat shall make available a qualified legal expert from the WTO technical cooperation services to any developing country Member which so requests. This expert shall assist the developing country Member in a manner ensuring the continued impartiality of the Secretariat.

\footnotetext{
92 These are outlined in a series of sections on Developing country Members in dispute settlement theory and practice; Special and differential treatment and Legal assistance.

93 See WTO, Developing countries in WTO dispute settlement <https: / /www.wto.org/english/tratop_ e/dispu_e/disp_settlement_cbt_e/c11s1p1_e.htm>.
} 
For this purpose the Institute for Training and Technical Cooperation, which is a division in the WTO Secretariat, currently employs one fulltime official and, on a permanent part-time basis, two independent consultants. In their roles they assist developing country Members by rendering advice about WTO laws and procedure. They are however, required to always act in a manner that still ensures the continued impartiality of the Secretariat (Article 27.2 of the DSU). As a result therefore, they cannot assist in drafting submissions as this would be in violation of the neutrality obligation of the Secretariat. ${ }^{94}$ The WTO Secretariat also conducts periodic special technical training activities in Geneva and in the capitals of member states (Article 27.3 of the DSU).

\section{B. The Advisory Centre for WTO Law}

The creation and operation of an Advisory Centre on WTO Law (ACWL) is another means by which states part of the WTO are being assisted and subsidised with regard to access to justice. The Advisory Centre which became operational in 2001 is a dedicated and resourced "legal aid" Centre and is essentially an independent intergovernmental organization. It is important to note that this body is separate and independent from the WTO. ${ }^{95}$

There are currently 30 members. Every WTO Member, whether a developing country or not, as well as countries and independent customs territories in the process of accession to the WTO, can become members of the Advisory Centre. Each member country contributes to the ACWL. The rates applied to a developing state for legal consultation would depend on the country's size and economic solvency. The system places special emphasis on the LDCs by automatically granting them access to its services. ${ }^{96}$

The usefulness of this unique body is attested to by the fact that between 2001 and 2008 alone the ACWL provided support in thirtyseven proceedings, which constituted over $20 \%$ of litigations during that time. As of 2014, the ACWL provided over 2000 legal opinions, and gave legal support in 45 dispute settlement proceedings. In nearly half of

\footnotetext{
${ }^{94} \mathrm{~K}$ van der Borght, The Advisory Center on WTO Law: Advancing Fairness and Equality, 22 Journal of International Economic Law (1999) 723.

95 It was established by an international agreement signed by 29 Members of the WTO in Seattle on 1 December 1999, the Agreement Establishing the Advisory Centre on WTO Law. This Agreement entered into force on 15 June 2001 and the official opening of the Advisory Centre took place on 5 October 2001.

96 J Bohanes \& F Garza, Going Beyond Stereotypes: Participation of Developing Countries in WTO Dispute Settlement, 4 Trade L \& Dev (2012) 45
} 
those disputes (about 42 percent) the pertinent developing countries stood in opposition to more successful industrialised economies. ${ }^{97}$

C. Developing Countries and Least Developing Countries' performance in the Dispute Settlement System

Access of developing states to the DSS as discussed above is therefore, quite impressive and commentators like Renato Ruggero, have expressed the belief that the DSB better serves the interests of Developing countries and LDCs, as a rule-based system than as a power-based system. $^{98}$ Despite this quite common view, it is notable that the participation rates from small DCs and LDCs has not been exactly liberal.

While privileged states such as the so called quad countries, i.e. US, EU, Canada and Japan, have always held the advantage of being able to easily afford a full-time legal task force, only a small number of developing states have successfully exploited the system. For instance, Argentina, Brazil, Chile, China, India, Mexico, South-Africa, and Thailand are well placed to use the system to their advantage. However, these countries are not the typical developing states. On the contrary some of them are the fast developing, contemporary booming economies. ${ }^{99}$

It is instructive to note that while five particular developed states alone account for $60 \%$ of complaints, only $40 \%$ of complaints have been filed from among the ranks of developing States. Indeed only thirteen countries account for $90 \%$ of cases. To date, no African country or Middle Eastern economy has ever brought a complaint in the WTO. Among LDCs, only Bangladesh has ever instituted a WTO complaint. ${ }^{100}$ It is now necessary to look at other non-court dispute resolution.

\section{The International Centre for Settlement of Investment Dispute}

A popular if not highly recommended route in 'Multinational versus State' dispute scenarios is dispute settlement via the International

\footnotetext{
97 Johannesson, supra note 91 at 8 .

98 R Ruggero, The future path of the multilateral trading system (17 April 1997) <http://www.wto.org/ english/news_e/pres97_e/seoul.htm accessed 9/2/2015>; K van der Borght, Justice for All in the Dispute Settlement System of the World Trade Organization? 39 Ga. J. Intl \& Comp L (2010-2011) 787 (http:// digitalcommons.law.uga.edu $/$ cgi $/$ viewcontent.cgi?article $=1064 \&$ context $=$ gjicl $>$.

99 Ibid.

100 Ibid.
} 
Centre for Settlement of Investment Disputes (ICSID). ICSID is a public international organization created under the Convention on the Settlement of Investment Disputes between States and Nationals of Other States (the ICSID Convention). ${ }^{101}$

The cost of dispute settlement at the ISCID (just as with the case of the WTO) is notoriously high and is deserving of ameliorating measures through legal aid. Clearly the inherent risks in multinational investment for instance, in the oil industry are formidable. Investors are exposed to various dangers exacerbated by chronic instability in political leadership and social conditions in many parts of the developing world. This can be a source of frustration for multinationals but the recent experience of ICSID has shown that when corporations kick-start an action under the ICSID route they tend to succeed in their claims. Therefore, the ICSID route is seen as particularly user friendly for corporations in espousing their claims in the developing world. As the website of the organisation acknowledges:

With the influx of cases based on general consents of the States in the laws and treaties, only a minority of the proceedings before the Centre today concern disputes exclusively over the performance of investment contracts concluded by the State. The cases now more typically concern claims over such events as civil strife in the State, alleged expropriation or denials of justice by it, and actions of its political subdivisions. ${ }^{102}$

ICSID offers rules designed specifically for the resolution of international investment disputes between investors and States. ${ }^{103}$ The two main instruments involved here are the ICSID Convention ${ }^{104}$ and the ICSID Additional Facility, ${ }^{105}$ which provide the procedural framework for arbitration, conciliation and fact-finding proceedings. This framework is supplemented by a network of detailed Regulations and Rules.

101 The Convention was formulated by the Executive Directors of the World Bank and submitted by them on March 18, 1965 to member States of the Bank for consideration with a view to signature and ratification. The Convention, entered into force on 14 October $1966<\mathrm{http}$ // www.worldbank.org/icsid/ cases/cases.htm>.

102 ICSID, A Guide to ICSID <http://www.worldbank.org/icsid/cases/cases.htm>.

103 The official documents of ICSID include: The ICSID Convention ICSID Convention; Report of the Executive Directors on the Convention; Administrative and Financial Regulations; Institution Rules; Arbitration Rules; Conciliation Rules; ICSID Additional Facility Rules; Arbitration (Additional Facility) Rules; Conciliation (Additional Facility) Rules; Fact-Finding (Additional Facility) Rules <https://icsid.worldbank. org/en/pages/icsiddocs/overview.aspx>.

${ }^{104}$ Convention on the Settlement of Investment Disputes between States and Nationals of Other States 575 UNTS 159.

${ }^{105}$ ICSID Fact-Finding (Additional Facility) Rules offer parties the opportunity to constitute a Committee for the purpose of conducting inquiry into and report on relevant circumstances in the pre-dispute phase. Their intent in such instances is to avoid legal disputes by providing an impartial assessment of facts arising in a business or other contractual dispute between the parties. 
The Centre also handles arbitration cases under other rules, such as the UNCITRAL Arbitration Rules, and ad hoc investor-State and State-State cases. The Centre's services may include mediation of investment disputes and other alternative dispute resolution mechanisms.

ICSID claims may involve hundreds of millions, and in some circumstances will exceed a billion dollars. Not surprisingly the costs of resolving such disputes can also reach millions of dollars, yet in many senses the ICSID mechanism has become a veritable theatre of SouthNorth economic conflict resolution. ${ }^{106}$ This is what an author describes as: injustice created by the arbitration system in forcing developing and economically crippled countries to defend themselves at great cost and with a substantial likelihood of losing a judgment equal to a substantial percentage of their national budget.'

ICSID arbitrators play a crucial and continuing role in the workings of this system and for this they receive considerable pay. ${ }^{108}$ Generally advances paid to and received by the tribunal cover the fees and expenses of the Tribunal, Commission or ad hoc Committee members. Currently each member is entitled to receive: a fee of US\$3,000 per day of meetings or other work performed in connection with the proceedings (corresponding to US\$375 per hour); and the reimbursement of any expenses reasonably incurred in connection with travel and otherwise, including a per diem. ${ }^{109}$ The fees and expenses may not exceed the amounts in the Memorandum and Schedule of Fees, ICSID arbitrators may even request by application through the Secretary-General for a higher amount, under special circumstances (see Article 60 of the ICSID Convention and Administrative and Financial Regulation 14 (1)). ${ }^{110}$

Given that most ICSID cases are largely initiated by Western investors against developing states, the accusations of economic

${ }^{106}$ For instance, in Libananco Holdings Co Limited $v$ Republic of Turkey, the claimant requested \$24 million in costs and fees for a claim worth approximately $\$ 10$ billion. By including legal fees, witness, expert fees and various incidental expenses, the costs of the parties make up the majority of the parties total expenses. JY Gotanda, Consistently Inconsistent: The Need for Predictability in Awarding Costs and Fees in Investment Treaty Arbitrations, 28 ICSID Review (2013) 1, 24.

107 C Olivet, The Dark Side of Investment Agreements, Transnat'l Inst. (Dec. 2011) 1, $4<$ http://www.tni. org/sites/www.tni.org/files/the_dark_side_of_investment_treaties-final.pdf $>$.

108 See, also, N Buxton, Transnat'l Inst. \& Corp. Eur. Observatory, Legalized Profiteering? How Corporate Lawyers Are Fuelling an Investment Boom (2011) 1, 4-6 <http://www.sierraclub.ca/en/mainpage/legalized-profiteering-how-corporate-lawyers-are-fuelling-investment-arbitration-boom $>$.

109 The expense entitlements are explained in the Memorandum on the Fees and Expenses of ICSID Arbitrators. The fee entitlement is contained in the Schedule of Fees. See ICSID, Cost of Proceedings $<$ https:/ / icsid.worldbank.org/en/Pages/services/Cost-of-Proceedings.aspx >.

${ }^{110}$ Chapter III Financial Provisions Regulation 14, Direct Costs of Individual Proceedings <http:// icsidfiles.worldbank.org/icsid/icsid/staticfiles/basicdoc/partc-chap03.htm\#r> at 14. 
bullying are only further buoyed by the exorbitant costs of financing the resolution of the disputes. ${ }^{11}$ ICSID dispute settlement as an experience has been quite traumatic for developing states and the global financial crisis of the first decade in this century only served to accentuate the problems. By 2009 the president of Ecuador denounced ICSID arguing that investment regime signified colonialism and slavery with respect to its subservience to the interests of transnationals. ${ }^{112}$ Similar sentiments were repeated by the President of Bolivia at a UN conference in June 2009. FDI in most developing states are relatively small and concentrated in few sectors. Disputes arising out of FDI are very important for smaller states and in the event of their occurrence, questions relating to access to justice loom large as a result of the significant imbalances in the capacity of countries and firms to negotiate agreements and engage in dispute settlement processes'. ${ }^{113}$.

The imbalances occur through a plethora of means and they include the fact that qualified ICSID arbitrators are disproportionately from developed states where most investors also emanate from. Also, the ICSID hearings take place in expensive cities like Paris and London placing additional costs implications on indigent states.

In addition, ICSID arbitrations are perceived as slow, hard to manage and unpredictable. The difficulties are not easily surmountable as investment arbitrators are usually ad hoc appointees and the hearings are conducted privately, giving ground for less public understanding about how the ICSID functions. Furthermore, third parties, including civic interest groups, are permitted to participate in proceedings only if there is a double assent by the disputing parties specifically consenting to the access or if the applicable investment treaty so provides. This restriction may unnecessarily contribute strictures to access to justice as such consent might be withheld by the party with better tools and resources than the indigent party thereby limiting the ability of the weaker party to defend itself or enforce a legal right. ${ }^{114}$

\footnotetext{
111 The number of Western European states that were ever called upon to answer charges before ICSID tribunals in Washington or elsewhere was limited to a mere one percent. W Kidane, The China-Africa Factor in the Contemporary ICSID Legitimacy, 35 U Pa J Intl L (2013-2014) 559, 563.

112 See, P Singh, The Rough and Tumble of International Court and Tribunals, 55 Indian J Intl L (2015) 329-366 noting that international adjudication were used to ghostwrite pro-capital norms in international law's sources.

113 United Nations, Investment Support Programme for the Least Developed Countries (ISP/LDCs) Programme Document (6 September 2017) <https://www.un.org/ldcportal/new-investment-supportprogramme-for-the-ldcs $/>$.

114 See generally, LE Trakman, The ICSID under Siege, 45 Cornell Intl L J (2012) 603.
} 
It is worthy of note here that a similar imbalance in the initiation of proceedings noted of the WTO exists also in relation to ICSID and that the legal aid schemes in place in both cases help to rebalance the situation.

\section{The ICSID's system of cascading costs, fees and contributions and sui generis schemes}

The costs in cases governed by the ICSID rules consist of: (i) The parties' expenses, including the cost of legal representation; ${ }^{115}$ (ii) The advances paid to ICSID to cover the fees and expenses of arbitrators, conciliators or committee members, and the Centre's expenses and administrative charges; and (iii) The lodging fee paid by the party instituting proceedings. ${ }^{116}$ ICSID periodically requests for Advance Payments throughout the life of a case (usually for three to six months). Such payments cover the costs of the proceeding (Administrative and Financial Regulation 14(3)) and are estimated in consultation with the President of the Tribunal, Commission or ad hoc Committee. The first advance payment is requested shortly after the constitution of the Tribunal and is usually in the order of US\$100,000 - US\$150,000 per party. Clearly the total cost of the proceeding paid from the parties' advances would depend on the complexity of the case, its length as well as the number of pleadings and oral hearings. ICSID's expenses and administrative charges are considerable. Although the Centre does not charge the parties for its services by the hour it does charge a hefty annual fee of US $\$ 42,000$ to be divided equally between the parties (see the Schedule of Fees). ${ }^{117}$

The fee covers time spent by all members of the dedicated case team, including the assistance of the Secretary at hearings and the financial management of the case account. Additional services by other service providers, e.g., costs of interpretation, court reporting, catering, videoconferences and courier, are paid from the parties' advances. It may be noted that generally in arbitration, each party pays one half of the advances, although the Tribunal may order a different apportionment at any stage of the proceeding (Arbitration Rule 28, Article 58 of the Arbitration (Additional Facility) Rules). The allocation of costs during

\footnotetext{
115 A Tribunal or ad hoc Committee has discretion to order that these be reimbursed.

${ }^{116}$ A non-refundable Lodging fee of US\$25,000 is payable to the Centre by a party: requesting the institution of conciliation, arbitration or fact-finding proceedings under the ICSID Convention or the Additional Facility; or applying for annulment of an award rendered under the Convention.

${ }^{117}$ Schedule of Fees (Effective 1 July 2017) <https://icsid.worldbank.org/en/Pages/icsiddocs/Scheduleof-Fees.aspx>.
} 
the proceeding is of course without prejudice to the final decision on costs to be made by the Tribunal in the award (Article 61(2) of the Convention, Article 58 of the Arbitration (Additional Facility) Rules). In conciliation cases, the costs of the proceeding are again borne equally by the parties and each party bears its own legal fees and expenses (Article 61(2) of the Convention, Article 40 of the Conciliation (Additional Facility) Rules).

In many ways the burden of costs actually lies more on the part of largely indigent state parties. This is reflected in the position of the author who persuasively notes: '[T] he private investor is almost always the party who initiates the process. If the investor is not afraid of being penalized for bringing a non-meritorious claim through the allocation of cost, it would have fewer disincentives to try its chances. The state's costs are likely to be higher in most instances because the respondent states arbitrate cases in the investor's home state or at least continent and therefore the state has to hire attorneys there in addition to paying for transportation and accommodation of in-house counsel, government officials, and covering expenses for fact and expert witnesses as well as translation and interpretation services. ${ }^{118}$

A. Non-Court Based Legal Aid: International Development Law Organization

With a view to support the above argument for third party participation, the International Development Law Organization (IDLO) on September 6, 2017 released a new investment support program for indigent states. The program is designed to provide advice and support investment-related negotiations and to assist in dispute settlement, such as international arbitration. This, it will do by providing, upon request, technical and advisory assistance for investment-related dispute resolution. The terms for such assistance could comprise legal expertise on investment and/or commercial arbitration. The IDLO has also made some more impressive operational arrangements including plans for:

1. a "Rosters of Experts" comprised of professionals with high standards of qualification, as well as firms or other organizations possessing expertise in legal as well as relevant non-legal fields, willing to provide assistance to

${ }^{118}$ Kidane, supra note 111 at 621. 
indigent states and other eligible private sector entities, upon their requests, on a pro bono basis, or on a substantially reduced-fee basis.

2. Establishment of collaborative arrangements and partnerships (preferably by way of Memoranda of Understanding-MoUs) with relevant national and international partners (e.g. law firms, professional partnerships, consulting firms, professional associations, universities, research centers, non-governmental organizations, and other providers of related technical assistance).

3. Invitations for specific experts, who are not on the Roster of Expert, as long as he or she fulfils all requirements to be included in the Roster of Experts and is prepared to provide services on a pro bono or reduced-fee basis.

4. Incorporation of local experts, and experts with a specific knowledge of the client's legal system. It will (according to its procedures) assume the costs of the travel and medical insurance of the $\operatorname{Expert}(\mathrm{s})$, as well as other expenses necessary for the conduct of the specific support activities (such as interpretation and translation costs). ${ }^{119}$

The value of this kind of an international organisation in enhancing access to international justice through arbitration cannot be overrated.

\section{B. The Office of Staff Legal Assistance}

The OSLA exists and renders legal assistance only as part of an internal department in the UN. ${ }^{120}$ The Office forms part of the UN's new internal justice system situated as it is within the Office of Administration of Justice (hereafter the OAJ) and is currently located in multiple places - New York, Geneva, Nairobi, Addis Ababa and Beirut. ${ }^{121}$ The OAJ has the overall responsibility for the UN internal dispute resolution facilities. ${ }^{122}$ This particular institution thus, has more to do with indigent persons than with states.

OSLA indeed is created to help staff members, former staff members or affected dependants of staff members, if they need legal advice and

\footnotetext{
119 Investment Support Programme For The Least Developed Countries (ISP/LDCs) Programme Document, 6 September 2017.

120 Office of Staff Legal Assistance Website <http://www.un.org/en/oaj/legalassist/.

${ }^{121}$ Office of Staff Legal Assistance Website http://www.un.org/en/oaj/unjs/office.shtml accessed 10 October 2018.

${ }^{122}$ R Gulati, The Internal Dispute Resolution Regime of the United Nations - Has the Creation of The United Nations Dispute Tribunal and United Nations Appeals Tribunal Remedied the Flaws of the United Nations Administrative Tribunal? <http://dx.doi.org/10.2139/ssrn.1695215>.
} 
representation in disputes with the UN. OSLA in giving advice makes no difference between individuals subject to a disciplinary case, or those appealing an administrative decision. ${ }^{123}$ The Office can advise staff members at any stage of the dispute as long as it is related to UN employment. OSLA generally aims to ensure that there is equality between the member of staff and the management during the dispute. ${ }^{124}$ OSLA's services are free by virtue of a trust fund created for the Office through which donations are received to fund the hiring of legal officers and support staff.

If a staff member seeks help with OSLA, he or she will be advised on the best way to handle the dispute. There are at most times two ways to settle the conflict; the formal and the informal way. If the Office deems that the dispute is best handled in formal ways, they can bring the dispute to the UN Dispute Tribunal. The tribunal is much like a litigation, and the Tribunal will give a verdict. This verdict can be appealed by both parties to the UN Appeals Tribunal. ${ }^{125}$ If the dispute is better solved in informal ways, the staff member can seek the help of the UN ombudsman as an alternative to litigation. The Ombudsman helps the staff member to identify alternate ways to solve the conflict, but he will not impose a solution on the parties. ${ }^{126}$ Mediation is also offered as an alternate to the UN tribunal's services. ${ }^{127}$

Although international civil servants are commonly perceived as well paid, it will appear that OSLAs services are well sought after and seen as valuable by UN staff. In 2014 OSLA received 1,180 new cases and closed or resolved 1,171 cases. Of these only 110 cases were settled in 2014, and only three of these were settled by either the Ombudsman or mediation. ${ }^{128}$ In comparison 4,400 people are employed by the UN worldwide. ${ }^{129}$ Only members of staff who are directly hired on a more permanent basis and definitely not those that are volunteering on projects have access to the help provided by OSLA. ${ }^{130}$ Member states

\footnotetext{
123 Office of Staff Legal Assistance Website, supra note 120.

124 Gulati, supra note 122 at 45, 48, 59.

${ }^{125}$ UN Appeal Tribunal Website available at http://www.un.org/en/oaj/appeals/ accessed on 10 October 2018.

${ }^{126}$ United Nations Ombudsman \& Mediation services <http://www.un.org/en/ombudsman/help. shtml>.

127 Ibid.

128 Office of Administration of Justice, Eighth activity report (1 January to 31 December 2014) at 21.

129 United Nations Career Website <https:// careers.un.org/lbw/home.aspx?viewtype=VD>

${ }^{130}$ United Nations, Request for assistance <http://www.un.org/en/oaj/legalassist/forms/osla $\%$ 20intake\%20form_distributed_v8.pdf $>$.
} 
and other intergovernmental organisations and their staff can as such not settle disputes with the UN with help from the OSLA.

OSLA's legal aid scheme is unique as a form of international legal aid because it is aimed at international civil servants. Although it applies to a narrow set of the class - i.e. UN staff, it does contribute appropriately to the law and practice of international legal aid. Hopefully this sort of aid has already set a very useful template that can be transplanted to and be adopted by other international organisations and intergovernmental agencies.

\section{A general critique of legal aid in international disputes}

When the idea of legal aid scheme for poorer states was first seriously discussed in the mid to late 1970s, the first real opposition came from a respected jurist from the developing world. ICJ Judge Taslim Elias from Nigeria took the view that:

The idea of introducing a legal aid scheme for developing countries, which some have advocated in recent years, should be discountenanced as these countries would view with suspicion and even resentment any offer of financial assistance or charity in the prosecution of their claim for redress before an international tribunal. ${ }^{131}$

This initial reservation about the proposals are not as surprising as it may appear now if account is taken of the peculiarities of the era in which they were expressed. This was the era of newly independent developing states emerging after many centuries of domination and exclusion from international law and international relations. Some of the new states mainly in the global south attained independence only after armed struggle and they continued to be faced with discrimination in many aspects of international relations. Indeed, the corpus of international law was still largely written without them in mind.

At this stage the problematic European jurisprudence still loomed large in the writings of older writers such as Wheaton, ${ }^{132}$ Westlake ${ }^{133}$ and Lorimer. ${ }^{134}$ Therefore, it was perhaps understandable that any

\footnotetext{
131 Elias' comments in ibid., 30-31; Cf. O'Connell, supra note 25 at 235-237.

$132 \mathrm{H}$ Wheaton, Elements of International Law (Stevens \& Sons, London, 1866) 17-18;

${ }^{133} \mathrm{~J}$ Westlake, International Law (The University Press, Cambridge, 1904) 40.

134 J Lorimer, The Institutes of the Law of Nations (London: William Blackwood and Sons, 1883) 101-102. We are also able to find unbecoming inscriptions of 'otherness' in such sources as follows: Georg Wilhelm Friedrich Hegel, cited in V.L Poliakov, The Aryan Myth: A history of racist and Nationalist Ideas in Europe (Basic Books, New York, 1974) 241. For more discussion of the inscription of the 'Other'. See, NC Manganyi, Making Strange: Race, Science and Ethnopsychiatric Discourse, in, Francis Barker et al, Europe and its others, vol. 1 Proceedings of the Essex Conference on the Sociology of Literature July 1984 (Univ Essex, Essex, 1985) $152 \mathrm{ff}$.
} 
proposition that would seem to reinforce stereotypes or perpetuate a condescending attitude by older and more powerful states was instinctively recoiled from. It is suggested that this is the reason why Judge Taslim Elias may have reacted against the idea of legal aid for developing states in such a manner.

It is no wonder that the idea of legal aid in the international sphere has gradually taken hold in an era when more balanced views of the origin, role, functions and potentialities of international law are commonly accepted. ${ }^{135}$ With growing confidence among the rank of developing states and with the evidence of fast developing states like China, India and Brazil there is more acceptance of the idea of international legal aid. International courts will have far less international relevance if access to them is reduced not by jurisdiction but by economic forces alone. The various aid funds discussed above among others have become one of the veritable means by which access to international courts can be achieved.

It is pertinent to note that apart from direct assistance to litigants and accused persons, there are other strands of legal aid of significance. Legal aid may take the form of donations to provide financial assistance to interns working in international tribunals. ${ }^{136}$ For instance, pursuant to the conclusion of a memorandum of understanding between ITLOS and the Korea International Corporation Agency (KOICA) in March 2004 , a grant of US\$150,000 was given by the latter to provide financial assistance to interns from developing countries. The aim is to enable them further participate in the Tribunal's Internship Programme. ${ }^{137}$ This commendable facility ought to be made available to other major institutions. The poor representation of interns who are African nationals at the PCA has been the subject of this author's commentary elsewhere. ${ }^{138}$ Suffice here to mention that in some years the internship programme run by the PCA will have only one African included in it.

A. Evaluating the Trends in international Law Adjudicative and Arbitral Courts and Tribunals

\footnotetext{
135 A Orakhelashvili, The Idea of European International Law, 17 European J Intl L (2006) 347.

136 We will discuss below the category of non-party entities that seek funding in international criminal trials and human rights proceedings.

1379 ITLOS Yrbk 2005 (Nijhoff Publishers, Leiden, 2006) 74.

${ }^{138}$ G Oduntan, Africa Before the International Courts: The Generational Gap in International Adjudication and Arbitration, 44 Indian J Intl L (2004) 738.
} 
It is necessary to recall here that the practice of establishment of funds by the UN has a long and noble tradition. Funds are established for various purposes such as to aid independence, to achieve post conflict resolution and of course to subsidise access to dispute resolution mechanisms. ${ }^{139}$ Typically the fund will be set up as a result of a resolution of the General Assembly and will contain the following principal provisions;

(a) That the resolution will authorise the Secretary - General and the pertinent UN body to launch appeals to governments for voluntary contributions to the established funds;

(b) That other corporations, organisations as well as natural and juridical persons are invited to make voluntary donations;

(c) appointment of the trustee of the fund (e.g. Namibian fund) or Panel of Experts (ICJ Trust Fund);

(d) (d). Appointment of an implementing Office for the fund which may be based in any of the UN offices or regional bodies. ${ }^{140}$

There is no doubt that the various Trust Funds can be one of the most important devices for facilitating access to these courts and tribunals. Yet a lot still has to be done to achieve the dream of granting access to all states that may need the service. In any case, not more than four states benefitted from the Fund in its first decade of its existence. ${ }^{141}$ After a decade of the announcement of the World Court's Trust Fund only about 35 States have contributed to the fund. Their total contributions barely crossed over half a million dollars. In 2009 which represents the 20th anniversary of the fund, its business may be said to have picked up slightly. In 2008 Djibouti attracted $\$ 290,500$, to defray its costs in prosecuting its gains in the Certain Questions of Mutual Assistance in Criminal Matters case. ${ }^{142}$

\footnotetext{
139 The UN Fund for Namibia, established on the basis of the report of the Secretary-General to the General Assembly at its 26th session 1/A/8473; resolutions 2679 (XXV)of 9 December 1970, 2872 (XXVI) of 20 December 1971 and 3030 (XXVII) of 18 December 1972.

140 The United Nations Office for West Africa (UNOWA) handled the Trust Fund for the CameroonNigeria implementation process whereas the office of legal Affairs is the Implementing Office for the ICJ Trust Fund and it provides the services required for the operation of the Fund (Secretary Generals Trust Fund, Article 13).

141 ICJ Yrbk (1992-1993) 249.

${ }^{142}$ Report of the International Court of Justice Secretary-General's Trust Fund to Assist States in the Settlement of Disputes through the International Court of Justice Sixty-third session Item 69 of the provisional agenda, United Nations A/63/229 at 2 <http://daccessdds.un.org/doc/UNDOC/GEN/N08/ 454/88/PDF/N0845488.pdf?OpenElement>.
} 
In 2004 the Fund received one joint application from Benin and the Niger to defray the expenses incurred in connection with the submission of their boundary dispute to the Court. On the recommendation of the Panel of Experts, US\$ 350,000 was awarded to each applicant. ${ }^{143}$ In 1997 Botswana and Namibia received limited financial assistance' from the Fund. In view of the Panel of Experts, the Fund's limited assets, made it necessary 'to strike a balance between encouraging recourse to the Court and the need to be in a position to accommodate future applications. ${ }^{, 144}$ On the whole it must be said that for the fund to become viable, more State Parties to the Court's Statute should be convinced to donate more to the fund.

Transnational and Multinational Corporations many of which operate profitably from developing States still have to be convinced to donate generously into the available trust funds and legal aid schemes available to states. While it must be stressed that donations to the ICJ Trust Fund should remain largely optional, States and Multinational Corporations that operate or have dealings in developing states must realise that there may be much more to lose in terms of business and investments and goodwill, if States often settle their disputes through armed conflict rather than through the international adjudicative or arbitral fora. The process of receiving funds through some of the existing Trust Funds and legal aid schemes is still in practical terms shrouded in mystery. There are some clear cases of need. Chad which was the first recipient of an award under the ICJ scheme appears to undoubtedly qualify for the aid. It is landlocked and has far fewer resources than its adversary -Libya (an oil rich African State). However, details of the award were for a long time not made public. In this way, the potential of the legal aid scheme as an international public relations asset for the World Court has been underutilised. Furthermore, exactly how the 'Experts' proceed in their consideration for funds arguably remains unclear till the present.

The Terms of Reference provide that the Fund will finance only two categories of cases. First, those brought by special agreement and

\footnotetext{
${ }^{143}$ Report of the International Court of Justice Secretary-General's Trust Fund to Assist States in the Settlement of Disputes through the International Court of Justice, General Assembly Distr.: General

21 September 2004, United Nations A/59/372 at $2<\mathrm{http}: / /$ daccessdds.un.org/doc/UNDOC/GEN/ N04/518/22/PDF/N0451822.pdf?OpenElement $>$.

${ }^{144}$ United Nations A/56/456 General Assembly Distr.: General 10 October 2001. Report of the International Court of Justice, Secretary-General's Trust Fund to Assist States in the Settlement of Disputes through the International Court of Justice Fifty-sixth session Agenda item 13 United Nations A/56/456 at 2 $<$ http:/ / daccessdds.un.org/doc/UNDOC/GEN/N01/574/81/PDF/N0157481.pdf?OpenElement>.
} 
second those brought by special agreement after a final decision has been reached and implementation is required. The first would include the border demarcation in Frontier Dispute, earlier referred to. ${ }^{145}$ Thus, the World Court Trust Fund may not be applied to cases submitted to the Court under its optional compulsory jurisdiction (Art. 36 (2) Statute of the ICJ or pursuant to provisions of other treaties in force. It may be argued that there is no clear advantage to be derived from these limitations. Legal disputes involving important treaties such as the Genocide Convention ${ }^{146}$ or the UNCLOS ${ }^{147}$ member states must not be discouraged from adjudication before the World Court just because they happen to involve states under the compulsory jurisdiction clause. To the extent that this is arguably what the Terms of Reference indirectly appears to achieve, the provisions may be inadequate and in need of revising.

In the case of the ICJ it appears that keeping these clauses outside the remit of legal aid under the Terms of Reference is principally for the purpose of avoiding situations where funds are spent on cases where one party may later refuse to cooperate. However, there is no concrete assurance that someday a state would not refuse to appear in a case even though it had agreed to submit the matter to the Court in a special agreement. Again, the refusal to supply funds in cases brought under the optional clause may invidiously become a disincentive towards the adoption of the optional clause. Cases submitted by consensus are thereby presented as more acceptable or perhaps more supportable by the international community. This undermines the fact that the two modes of establishing jurisdiction are of equal legality and that they are both ultimately based on the element of 'consent'. The current rules, may therefore, contribute to the painfully slow progress being made in advancing the acceptance of the compulsory jurisdiction of the Court under the Optional Clause as a form of consent post hoc. In sum the Trust Fund's organisation appears to give the Experts ample opportunity to interfere with the way developing states may wish to handle their cases. Furthermore it forms an ominous cloud over the Court's compulsory jurisdiction. ${ }^{148}$

\footnotetext{
145 See, Terms of Reference, supra note 27 [6]; [1986] ICJ Rep 554.

${ }^{146}$ Convention on the Prevention and Punishment of the Crime of Genocide, 78 UNTS 277 (entered into force on 12 Jan 1951).

147 UN Convention on the Law of the Sea, 21 ILM (1982) 1261; Misc 11 (1983), 8941; 1833 UNTS 3 (1994); I Brownlie, Basic Documents in International Affairs, 3rd edn (OUP, Oxford, 1983129.

148 O’Connell, supra note 25 at 238.
} 
The criticisms above do not detract from the need for and significance of the creation of the first ever global international legal aids scheme for States. It is both a victory for developing states as well as an indication of the sophistication of the human mind that dispute resolution through international litigation will no longer tend to be the preserve of richer and more powerful Western States. There is no point in drawing analogies between the relevance and potential success of this scheme and that of legal aid schemes in domestic society. The differences are fundamental. One indigent person may quietly lose his entitlements in a legal relationship in the municipal setting and life simply goes on. The prospect of an entire population waking up to discover that their geographical location or parts of it and property situated in it now falls within the territorial sovereignty of another state as a result of poorly handled international litigation, due to lack of funds can be real. Such unfortunate situations are indeed not far-fetched.

There is a possible argument that frivolous suits may emanate from various quarters if the entire cost of litigation before courts are borne by someone else. The fears of this situation arising are grossly overrated since legal aid rarely covers the entire costs of the proceedings. Most of the international legal aid schemes discussed above also retain a strong discretion as to who will be successful in applications. It is also common that the amounts eventually granted by the ICJ trust fund and that of the PCA are in many cases much less than what applicants requested. ${ }^{149}$

Legal aid for the older international courts is both a necessity and a progressive innovation. What remains to be done is for State Parties to the ICJ Statute and the PCA arrangements to fine tune the operation of the fund. Experts from developing states must be given priority position in the decision as to who gets what and how much out of the Fund. That the aid scheme has increased accessibility to the World Court's contentious jurisdiction has already been testified to by its judges. It only remains to see how such targeted aid by the various other international tribunals and institutions can help to meet the expenses of poorer litigant governments. ${ }^{150}$

\footnotetext{
149 Article 10 of the Terms of Reference of the PCA. Note also the limited aid given in the 1997 application of Botswana and Namibia to the ICJ Trust Fund.

150 Speech by Sir Robert Yewdall Jennings on the Report of the International Court of Justice, 86 Am J Intl $L$ (1992) 249.
} 
B. Evaluation of Trends in the Use of Trust Funds in the International Commercial/Economic Courts

In international life the better-resourced and the economically stronger party do particularly well in dispute settlement processes. This is more so in relation to the leading international commercial courts and tribunals. The good news is that most of the leading public international law focused courts and tribunals appear to have adopted the policy that as a matter of principle, poorer parties appearing before them ought to have a subsidised service of legal aid for indigent states and persons.

For international commercial disputes and disputes in relation to international economic law, it is clear that in both the ICSID cases (where the stronger party almost always initiates the process) and in the WTO cases, qualitative legal aid is of key value to the international system. The IDLO services and the provisions of the WTO-DSU articles $^{151}$ have also been of significance in offsetting the power imbalance between states. ${ }^{152}$ Indeed this has required preferential treatment particularly in favour of the LDCs during dispute settlement resolution (DSR). It is quite positive that it is in the world of economic high stake investments as represented by ICSID and WTO that the language of imperative of assistance to developing states appears to be clearest. In the case of the WTO there is indeed a positive discrimination in favour of the LDCs.

Positive discrimination in the context of subsidising the appearance of indigent states at the various fora for settlement of commercial and economic disputes is for the common good. In other words these schemes are also to the advantage of powerful states and corporations. It is important for all stakeholders to realise that the equality of arms promoted by the various schemes is vital for the legitimacy of the international arrangements represented by organisations like ICSID and WTO legitimacy. If for instance, inconsistent measures maintained by the WTO against LDCs go unchallenged, their confidence in the world trading system may be negatively affected.

Widespread failure to participate in the WTO-DSS would encourage tit-for-tat reactions and introduction of tariffs and prejudicial subsidies which in no time will severely disrupt international trade. Price

\footnotetext{
151 Article 4.10 Dispute Settlement Understanding, supra note 89.

152 Kidane, supra note 111 at 621; L Olson, Incentivizing Access to the WTO's Dispute System for the Least-Developed Countries: Legal Flaws in Brazil's Upland Cotton Decision, 23 Minn J Intl L (2014) 101.
} 
suppressing subsidies may force farmers in the developing world to produce and export more commodities in order to be competitive in the international market with detrimental effects on the social welfare of a country. ${ }^{153}$ It is thus, clear that legal aid at the right time and in the right place contributes not only to the international rule of law but quite directly to the international economic order.

\section{Trends in Legal Aid: International Criminal Courts and Human Rights Courts}

For international criminal proceedings there are good reasons to argue that states should be obliged to provide legal aid from their national purse to enable an impecunious defendant in an international criminal trial face a fair trial. Admittedly the expenses of an international criminal trial are somewhat sui generis and very steep. It may be onerous on states especially those that may be emerging from prolonged crises to have the burden of providing a first class legal aid scheme to suspects that may in fact number into many hundreds. ${ }^{154}$ As the example of the ICC's TFV shows, addressing the criminal activities of a post war state may involve funding over 50,000 lives directly and indirectly. It is important to note that the need for legal aid may crop up literally at any stage of the trial in an international criminal trial. For instance, even after the accused has opted for self-representation and he/she for any plausible reason cannot in the view of the court continue self-defence, the right to counsel and legal aid may come up for discussion.

As a writer put it 'the right to represent oneself must ...yield when it is necessary to ensure that the trial is fair.' When the right of access to counsel comes up for discussion they often turn on the choice of counsel and who pays for counsel, especially where the defendant is indigent. ${ }^{155}$ If ever the idea of international criminal courts is to survive this century it will be because international legal aid would have made significant contributions to international relations. The costs involved in this area are indeed steep and litigation here has a peculiar susceptibility to sharp increases whereas the humanitarian justification is undeniably significant. In the reporting period of 2008-2009 alone the Victims and Witnesses Section of the erstwhile ICTY facilitated 727 witnesses

\footnotetext{
${ }^{153}$ SJ Tania, Least Developed Countries in the WTO Dispute Settlement System, 60 Netherlands International Law Review (2013) 375.

154 See also Legal and Human Rights Centre, supra note 77 at 48.

155 S Jegede, Right to a Fair Trial in International Criminal Law, The Guardian, Nigeria (30 June 2009) 77.
} 
travelling to The Hague to give evidence. The Office for Legal Aid and Detention Matters serviced over 500 defence team members in cases in pre-trial, trial and appellate proceedings. ${ }^{156}$ Such levels of cost is both significant in cementing international practice as well as in denoting the financial challenges that may impede the further development of an essential doctrine.

The two erstwhile sister Tribunals -ICTY and ICTR shared certain essential features in relation to their legal aid schemes. Legal Aid Reform and the Development of a Lump Sum System for the ICTR were two important areas of collaboration and harmonization between the parties. ${ }^{157}$ The determination of eligibility for impecunious defendants was within the jurisdiction of the registry of both organisations. The necessity to prove impecuniosity appears to be required of defendants in international criminal trials more than it is on applicants before international human rights courts. Whereas there are complicated formulas and procedures to test whether and to what extent a defendant is impecunious it does appear that the applicants before international human right courts like the ECtHR have relatively less difficulty in proving impecuniosity. For individuals it appears that the most elaborate rules for determination of indigence are to be found in the rules of the ICC particularly its Legal Aid System. ${ }^{158}$

It is generally true as submitted by David Anderson that: '[a]pplicants for legal aid must show financial need in relation to an actual or a proposed case'. ${ }^{159}$ Yet it may be argued that a technical reading of the Rules of the ECtHR may entirely remove the requirement on an individual to show that he/she cannot pay wholly or in part, the costs for the case. Rule 94 states that: " $[t]$ he President of the Chamber may ...grant free legal aid to the applicant in connection with the presentation of the case' Rules 92 and 93 provide more details as to how an applicant may need to show his need for legal aid. This may include satisfying the formal requirements of filling forms and possibly the receipt of written comments by a Contracting Party. Yet it may be argued that these provisions do not remove the inherent power given to the Court to act suo motu.

\footnotetext{
156 See Report of sixty-fourth session (2009), supra note 32 at 4.

157 ICTR Newsletter May 2005 at 6.

${ }^{158}$ It involves many intricate details of enquiry including (1) The person's residence will be excluded from the Estimated Monthly Rent (EMR); Assets wealth - furnishings; Motor Vehicles and other real property; Monthly Subsistence Allowance (MSA) and monthly disposal means (MDM).

159 Anderson, supra note 15 at 400.
} 
This may appear to be a seemingly academic point to make as in reality judges will be unlikely to run after applicants with money. Judges would grant legal aid only in cases of clear need. But such inherent powers of a Court are not to be ignored and may be necessary where, for instance, the court decides that the quality of representation on behalf of the applicant will be significantly improved by proper remuneration to counsel which would only be made possible through the exercise of this discretionary power. The important question is whether such open discretion to award aid to criminal suspects ought to apply to all international criminal courts. Our preference here is to argue that such discretion ought to apply to individual international courts on a case by case basis. Important considerations would include the country(ies) where the court is situated and where the majority of suspects and perhaps victims that are to make appearances also come from.

The role of the international community in ensuring access to international justice arguably extends to ensuring that there is access within states to international standards of justice. It is in this light we must applaud attempts by the UN particularly to fund the creation of judicial and quasi-judicial tribunals in some developing states. Examples of these include the UN Trust Fund for the Khmer Rouge Tribunal ${ }^{160}$ and the United Nations Transitional Administration in East Timor (UNTAET). ${ }^{161}$

In other words international legal aid may in fact begin with investment in the creation of courts and tribunals and at the national and international levels. The international system has increasingly realised the need to create judicial institutions in states where a lacunae is created through the malicious or negligent 'destruction of the justice system' say by a retreating junta or occupying force as in the case of East Timor. ${ }^{162}$ The options open to the international community in these circumstances include;

\footnotetext{
160 The Khmer Rouge Statute makes provisions for the appointment of international judges, international investigating judges and an international co-prosecutor legislation. DA Mundis, New Mechanisms for the Enforcement of International Humanitarian Law, 95 Am J Intl L (2001) 934.

161 The UNTAET exercises judicial functions in additions to its executive, legislative and executive competences. For this and other issues concerning the deployment of a Multinational Force to East Timor. See, SD Murphy, Contemporary Practice of the United States, 94 Am J Intl L (2000) 105.

162 See, H Stohmeyer, Collapse and Reconstruction of a Judicial System: The United Nations Missions in Kosovo and East Timor, 95 AJIL (2001) 46, 50-51; in the wake of a retreating Army it is possible that many other central civil services such as health services suffer from the "violent withdrawal". Andrew Rosser, The First and Second Health Sector Rehabilitation and Development Projects in Timor-Leste, Background Document: Making aid work in fragile states" case studies of effective aid-financed programs <http:/ / www. oecd.org/dataoecd/31/63/34252765.pdf $>$.
} 
(a) providing funding for the creation of ad hoc international tribunals (e.g. ICTY, ICTR);

(b) providing funding for the creation or resuscitation of national judicial structures;

(c) creation of Mixed Tribunals (consisting of national and international judges e.g. the Khmer Rouge, the Sierra Leone and Cambodian situations).

In the scenarios identified above the traumatic events that attend the immediate history of the affected states and people would usually be the rationale for the creation of these courts. In other words it is possible to locate the rationale for international legal aid as an aspect of humanitarian legal practice. The concerned developing states involved are usually in dire straits and may be unwilling or unable on their own to fund qualitative tribunals. Creation of the requisite courts and tribunals through the help of the international community may be the only meaningful way for a semblance of justice according to international standard to take place.

In many cases the egregiousness of the actions of the villain regimes or accused persons would in fact dictate that the judicial processes after the crises must take place under international scrutiny. In other words, there are reasons of international policy to ensure that proper trials take place and requisite punishment meted out to perpetrators of crimes under national and/or international laws. If the funding needed is to resuscitate a network of municipal or national courts or an entire judicial system, the costs may be quite prohibitive and the international system may be interested in merely kick-starting the system and leaving the affected state to take over financial and administrative control as soon as possible.

The fact, however, is that half-hearted efforts at the nascent stages may end up nullifying the whole effort in the long run. Inadequate funding and poor remuneration of judges and key staff may allow the evil of corruption to take root in the court(s) system. On the other hand, it is quite easy to see how the flow of massive funding to the judiciary or particular special courts may appear frivolous in the face of competing developmental or survival needs of a traumatised or transition state. Thus, ironically the creation of an international tribunal with a life span naturally determined by the life of the case(s) it is seised off, may be a cheaper option. The sums involved here are again not negligible as international jobs would have to be awarded and where 
the tribunal is based in a foreign territory such as at The Hague, the costs of transport lodging and remuneration of staff are bound to be considerable. If, however, the mixed ad hoc tribunal model is used (foreign and national judges) the costs are also considerable as even national judges may have to earn international salaries.

D. Defraying the Cost of Implementation of International Judgments and Awards

Aside from the costs of litigating before an international court there is also the cost of implementation of an international judgment. This aspect of access to justice is often overlooked in comparison to the more familiar problem of high costs of access to international courts. It is, however, an issue deserving separate mention here principally because it is the possibility and commitment of the parties to implementation of the judgment or award that is the rationale for engaging in international dispute settlement in the first place. ${ }^{163}$ It is unusual that the body, which renders a judgment, opinion or award, will also facilitate its implementation. Thus, the legal aid scheme of the particular dispute resolution mechanism that handled the dispute would ordinarily not be in a position to handle the post judgment/award phase where implementation happens. ${ }^{164}$

However, particularly in litigation between states, once a decision has been reached, the cost of translating this judgment literally from paper into reality would entail new and not negligible expenditure. Where for instance, the decision has delimited a territory, actual demarcation will have to be effected usually at astronomical costs. Where the parties to the dispute are developing states they may realise the need to seek funding from various sources - voluntary donations from friendly states, foundations, MNCs, and individuals as well as from contributions from trust funds.

\footnotetext{
163 As was written with respect of the Dispute Resolution mechanism of the WTO 'Disputes in the WTO are essentially about broken promises. WTO members have agreed that if they believe fellow-members are violating trade rules, they will use the multilateral system of settling disputes instead of taking action unilaterally. That means abiding by the agreed procedures, and respecting judgements.'

164 Exceptions to this are rare but not negligible and this is, for instance, the case in the Eritrea -Ethiopia dispute. The Eritrea Ethiopia Boundary Commission (EEBC) was established as a result of the protracted Eritrea/Ethiopian border crises and in accordance with the Algiers Peace Agreement of 12 December 2000 (Article 4) (Also referred to as the December Agreement. See UN Docs S/1999/32 and S/RES/1227 (1999). The Eritrea Ethiopia tribunal was later by the agreement of the parties constituted into a demarcation tribunal.
} 
The experience of Cameroon and Nigeria over the last fifteen years is instructive. After the judgment in the Land and Maritime Boundary between Cameroon and Nigeria in 2003 the parties became faced with the reality of an expensive implementation process. ${ }^{165}$ The Mixed Commission set up for the purpose of implementing the judgment soon enough realised that raising funds for the exercise is a challenging prospect as it involves the demarcation of about 2000 kilometres of boundary territory. ${ }^{166}$

The parties set up a Sub-Commission on Demarcation which made significant progress in its work as a result of the friendly contributions of donor states although it had commenced field assessment and data collection and analysis before the funds were contributed. To achieve its aims the Mixed Commission embarked on shuttle fund raising diplomacy in 2004 taking it to London, Paris, Washington DC and New York, as well as to the African Development Bank in Tunis. Consequently, the body succeeded in attracting a voluntary contribution of European Commission, $€ 320,000$, from the European Commission; the United Kingdom donated $£ 1$ million and Canada, 273,508 (Canadian dollars). ${ }^{167}$

The state parties - Cameroon and Nigeria contributed \$3 million each. The donations obviously provided the much needed confidence to embark on the expensive land and maritime demarcation. Furthermore there was a sense in which the involvement of the international donor community helped to secure the determination of the parties to attain the necessary objectives at a quite early stage after the judgment was rendered. The parties were indeed aware 'that the major players in the international community are watching very carefully' the progress of the implementation of the ICJ judgment. ${ }^{168}$

The financing of judgment implementation activities and projects allows friendly states to contribute to the process in a non-contentious manner based on the consensus of the affected parties. It may well be that such aid is the only permissible or justifiable way the donating state

\footnotetext{
165 ICJ decisions are available at <http://www.icj-cij.org/icjwww/idecisions.htm>.

${ }^{166}$ See also the Cameroon-Nigeria Mixed Commission, Sub-Commission on Demarcation of the Land Boundary Application for Funds to the Donor Community July 2003, p. 1.

167 Letter dated 28 September 2006 from the Secretary-General addressed to the President of the Security Council, United Nations S/2006/77, (29 September 2006) <http://daccessdds.un.org/doc/UNDOC/GEN/ N06/545/67/PDF/N0654567.pdf?OpenElement>.

168 Opening Address by Mr. Cheick Oumar Diarrah Chairman of the Working Group on Maritime Boundary. See, G Oduntan, The Demarcation of Maritime Boundaries in the Gulf of Guinea in Accordance with World Court Judgment in the Land and Maritime Dispute Case, 5 Romanian J Intl L 2007) 118-146.
} 
could have intervened under its national laws. While it may be diplomatically inconvenient to contribute to the legal defence of another state while the case is before an international court, it is less so if aid is supplied to achieve implementation of a judgment. Activities to be funded would typically be for non-controversial things such as building a cross border road/bridge or provision of technical training. Implementation aid may simply be done by donating experts in particular activities such as cartographers, lawyers or surveyors.

Thus for instance, Norway provided legal training on cross boundary pipelines to Cameroon and Nigeria ${ }^{169}$ It is of course not insignificant that Norway is a leading legal jurisdiction in oil and gas law as well as in the activity of oil and gas exploitation. It is also significant that the parties did ask for more of this targeted aid. They requested that 'the Expert should continue to advise the Working Group on the practical steps to facilitate completion of final agreements on cross-border cooperation'. ${ }^{170}$

These types of donations may also come from other donor bodies such as International NGO's, foundations and even corporations. In 2008, the German government, through the GTZ Foundation, allocated about 3.35 million Euros to support AUBP related activities and some part of the budget was provided as direct support to the demarcation of parts of the Mali/Burkina Faso boundary, as well as activities relating to the delimitation and demarcation of Mozambican borders with some of its neighbours.

A very simple but important form of aid may take the form of assistance in the acquisition of documents relevant to the dispute. In boundary delimitation and demarcation exercises provision of materials from colonial archives for free may be of significant help to developing states. Scholars and researchers may be provided with accommodation and/or free access to archives including copying or borrowing

\footnotetext{
169 During its twelfth meeting in Yaoundé on 12 March 2008, a joint maritime working group was presented with a masterclass coupled with detailed presentations on the subject by a Norwegian Expert attached to the UN Team as part of a donation by the Norwegian government to assist the Cameroon Nigeria process. A second lecture/presentation was given at the Thirteenth Meeting of the Working Group held in Abuja on the 18th of June 2008. The aim of the donors was to foster a cooperative game strategy in relation to the oil and gas fields straddling both states' common maritime boundaries.

${ }^{170}$ See Paragraph 18 'Decisions taken by the Working Group' Report of the Thirteenth Meeting of the Working Group on the Maritime Boundary Abuja, 18 June 2008. G Oduntan, International Law and Boundary Disputes in Africa (Routledge, Oxford, 2015) 48, 230, 233.

${ }^{171} \mathrm{AU}$, 'Conclusion of the 2nd International Symposium on Land, River and Lake Boundaries Management', Maputo, Mozambique 17-19 December 2008; see paragraph VII, pp. 3-4. See, also, A Zwane, Border restoration: more work ahead of 2017 Deadline, Swazi Observer (2 August 2014) <http://www. observer.org.sz/news/64579-border-restoration-more-work-ahead-of-2017deadline.html>.
} 
facilities. ${ }^{172}$ On the whole there is much more scope for wider use of non-cash based aid in international practice.

\section{Indices of a progressive system for international legal aid}

The law and practice of international legal aid is fast approaching the status of customary international law. The general features of the emerging custom has been fleshed out in the preceding pages of this paper. The following table attempts to present the information comparatively in the form of a table. The table only attempts a cursory appraisal of some of the features of the existing courts and is in no way a complete treatment of the issues addressed by the courts, tribunals and schemes covered. After the table we also discuss some of the issues that future scholars and practitioners in this area need to fine tune in order to make this particular field of study more elaborate and mature as well as fulfilling for those who wish to improve upon the schemes to develop new schemes.

\section{A. The need to Eliminate or trim Wasteful Procedure}

In the early years of the 21st century, Lord Woolf, master of the rolls, criticised the existing court procedures of England and Wales for being too expensive, complicated, and slow and for producing an inequality of arms between rich and poor litigants. ${ }^{173} \mathrm{We}$ also have to inquire into whether and to what extent the procedures of international courts may be contributing to high cost of justice. The procedure of the leading international courts and tribunals has to be continuously but not frivolously rationalised for improvement in effectiveness and relevance. ${ }^{174}$

\section{B. Judges}

It may be important to admonish judges to include access to justice within the purview of their judicial tasks. It has been well observed that 'international law and international tribunals have been both expanded' and that ' $[\mathrm{w}]$ ithin the disordered medley of international courts and

\footnotetext{
172 Oduntan, supra note 170 at 123.

${ }^{173}$ See, Harry Woolf, Access to Justice: Final Report to the Lord Chancellor on the Civil Justice System in England and Wales: July 1996 (HMSO, London, 1996). P Thompson, Woolf s Litigants, New LJ (27 February $2009)<$ https:/ / www.newlawjournal.co.uk/ content/woolf $\%$ E2\%80\%99s-litigants>.

174 Some good work exist in this area. See DW Bowett $\&$ ors., The International Court of Justice: Efficiency of the Procedures and Working Methods, 45 Intl \& Comp L Q (1996) 524.
} 
tribunals, a conscious effort on the part of international judges to maintain coherence may be required'. ${ }^{175}$ To this extent judges and arbitrators in international courts may have to play a greater role in limiting the incidences of costs as a matter of international policy. Their judicial instinct may have to be sharpened against inefficient procedure and they need to be biased in favour of rationalisation of procedure. Indeed the leadership and the rank and file of the administration of the existing courts and tribunals can help in the removal of all impediments, inefficiencies and wastages. It is in this light that we recall with approval the detection of waste and application of sanctions by the registry of the ICTR when it removed an erring solicitor for inducing wastage of scarce funds by apparently fraudulent means. ${ }^{176}$

Another way judges can help parties to reduce costs is to nudge them tactfully towards negotiation or other appropriate dispute resolution technique that may reduce the incidents of costs. There is no area of international disputes that negotiation is not capable of resolving even better than all other forms of third party adjudication. ${ }^{177}$

In some ways the noble duty to hustle for legal aid funds may also fall on judges. Judges have been known to gently hassle member states of international organisations for funds. The President of ITLOS impressively had occasion to say of the ITLOS finances:

The financial situation of the Tribunal remains far from satisfactory. As of 9 October 2000, there was an unpaid balance of assessed contributions to the overall budget of the Tribunal in the amount of $\$ 1,791,009$. I regret to inform you that as many as 35 States Parties to the Convention have never paid their assessed contributions. Timely payments of contributions have an important bearing on the ability of our Tribunal to discharge its functions effectively. ${ }^{178}$

The plea for funds and proactive attitude expressed in the above quote will in time, prove to be good practice in the face of apathy expressed by states towards payment of their financial commitment to international organisations and particularly international courts. All stakeholders in the temple of justice have a duty towards

\footnotetext{
175 Anderson, supra note 15 at 400.

176 Reference is made here to the fate of UK Solicitor Mr. Andrew McCartan. See, supra note 73.

177 A Plantey, International Negotiation in the Twenty-First Century, Translation by Frances Meadows, (Routledge-Cavendish, New York, 2007) at 67. See, also, Merrils, supra note 4 at 1-25.

${ }^{178}$ Statement by Judge P. Chandrasekhara Rao, President of the International Tribunal for the Law of the Sea, on Agenda Item 34 (A) At the Plenary of the Fifty-Fifth Session of the United Nations General Assembly, 30 October 2000, Press 39/Add.1 (14 November 2000) at $3<$ https://www.itlos.org/fileadmin/itlos/ documents/press_releases_english/press_release_39-Add.1_en.pdf $>$.
} 
advancing the cause of international dispute settlement though formal structures.

\section{Determination of Eligibility for Legal Aid}

There are clearly no reliable and/or predetermined rules of universal significance which can be referred to in determining which states are eligible for international aid generally. It is more so difficult to determine which state deserves aid to prosecute or defend claims before international courts and tribunals. In addition to the generally recognised and politically correct "developing states" there is the politically incorrect 'third world states' and 'poor states' nomenclatures to deal with. Economists have created so many classifications among developing states that it becomes confusing on economic terms alone to decide which states present the best claim to certain types of legal aids such as the one under discussion. There are the austere classifications of 'Least developed states' and even the frightening categories of 'Low Income Countries under Stress (LICUS)' and fragile states. ${ }^{179}$ It would appear impossible to judge the countries that would need legal aid on such classifications alone. The insufficiency of such categories is revealed in the arbitrary classifications that abound.

A possible solution is to adopt the criterion that international legal aid ought to be considered in favour of any state that applies for such aid. It is true that developing states in the immediate aftermath of a protracted civil or international conflict may present a clear need for financial aid in prosecuting its claims before an international court. It however, cannot be taken for granted that present day developed states may never in the future require this kind of help.

Sudden changes in fortune can also afflict richer states. It is suggested that in the immediate aftermath of a protracted civil or international conflict most societies may present a clear need for financial aid in prosecuting their claims before an international court. Developed states may at some time in the future also find themselves requiring economic aid including international legal aid. The grant of international legal aid towards a state will not be reasonable where that state is clearly in a position to shoulder the financial burden involved. Yet some

179 Core LICUS states include Burundi, Cambodia, Comoros, Congo, Democratic Republic of Congo, Guinea-Bissau, Kosovo (territory), Lao PDR, Nigeria, Papua New Guinea, Sao Tome and Principe, Tajikistan, Timor-Leste, Togo, Uzbekistan. Severe LICUS states include Afghanistan, Angola, Central African Republic, Haiti, Liberia, Myanmar, Solomon Islands, Somalia, Sudan, Zimbabwe. 
international courts have no clear criteria for determining economic impecuniosity for the purposes of legal aid.

It is possible to argue that the 'fast developing states' or what the OECD has termed major emerging economies such as Brazil, China, India, Mexico and South Africa would not qualify for international legal aid. ${ }^{180}$ With respect to this particular category of states, it appears that a self-enacting code of restraint which is already in place would be sufficient to prevent the disbursement of funds in their favour. India for example, refused foreign aid after the catastrophic Tsunami tragedies of 2004. It is perhaps of such states that late Judge Taslim Elias, a onetime President of the ICJ had actually said they 'would view with suspicion and even resentment any offer of financial assistance or charity in the prosecution of their claim for redress before an international tribunal. $^{181}$

\section{Conclusions}

The need for international legal aid schemes is clear in an imperfect world. The costs of international representation are considerable. Yet particularly in relation to the international commercial courts such as ICSID, corporate investors from developed states tend to bring more claims against developing states. Thus, because indigent states have less funds to defend their matters before international courts they continue to face the prospect of losing hundreds of millions in disputes. This underscores the importance of international legal aid to their economic fortunes. The problems developing states and their nationals face in international litigation include: first, complete inability to institute a claim at the major international courts and arbitral tribunals due to impecuniosity; second, the prospect of dilatory prosecution due to inability to secure quality legal representation; third, inability to effectively implement a judgment such as in territorial disputes without financial aid. In the emerging environment of proliferation of courts and tribunals, international legal scholars do have to ensure that indigent states and persons are able to access international justice and that they are not unduly dependent or hampered by their indigent status.

\footnotetext{
180 OECD work with G8: 6-8 June G8 Summit, Heiligendamm, German <www.oecd.org/g8>.

181 Elias' comments in Max Plank Inst, supra note 16 at 30-31.
} 
Note, however, must be taken that international legal aid in relation to commercial disputes may not include help in satisfying the judgment sums in financial terms such as in payment of fines and/or debts. It is however, suggested that help in securing expensive expertise such as cartographic experts, satellite imagery acquisition; and carrying out of studies that may be required in implementing a judgment are considered to be within legitimate types of legal aid. It is to be noted that other international courts actually deduct aid sums from the costs that may be awarded in favour of a party that has received aid. This was established in the Judgment of the ITLOS in the Juno Trader case when the tribunal decided that St Vincent and the Grenadines shall pay the costs of Guinea-Bissau incurred in connection with these proceedings, less any amount of financial assistance that may be provided to GuineaBissau by the Law of the Sea Trust Fund in connection with the case. ${ }^{182}$

Richer states may, however, consider it expedient to encourage settlement between poorer disputants by promising investment or other strategic help if the matter is quickly resolved by negotiations. The costs of coping with a breakout of military conflict is bound to be more prohibitive than a quick fix through international legal aid or economic diplomacy. The idea of a right to international legal aid for indigent states and persons is an appealing concept that ought to be further developed by lawyers, statesmen, regional institutions and indeed the United Nations. It is a happy situation indeed that a customary practice has emerged that states assist each other financially or in kind towards financing the adjudicatory or arbitrary resolution of disputes. It is also becoming part of customary international law at least since the Nuremberg trials that legal representation before international courts must be provided even where the accused persons cannot afford this. ${ }^{183}$

However, response to calls for contributions particularly to the public international law courts such as the ICJ and the PCA has been relatively low. The number of states that have benefited from the available schemes is also low. Yet the existence of the legal aid schemes maintained by these courts and the proliferation of schemes identified in

\footnotetext{
182 Press Release Judgment in Case No. 13, ITLOS <http://www.itlos.org/start2_en.html>.

183 The defense lawyers were either selected by the jailed defendants themselves or appointed by the Tribunal itself at their request. The chief counsels of the individual defendants, who also testified before the Tribunal, were supported by a total of 70 assistants, clerks, and lawyers. See, Google Cultural Institute, The defendants: Memorium Nuremberg Trials <https://museums.nuernberg.de/memorium-nuremberg-trials/ the-nuremberg-trials/the-international-military-tribunal/the-defendants/ $>$.
} 
this paper are important as a precedence for the future. Progress is however, difficult to measure as some of the courts do not appear to provide clear and easily accessible information on the number of states making contributions. Successive annual reports of the activities of the ICJ also appear to avoid naming specifically which states have benefited from the legal aid scheme perhaps for reasons of modesty.

Recent ICJ annual reports in the past 5 years have in fact altogether ignored mention of the Court's Trust Fund. All these arguably makes opaque an area of practice which inherently requires patent transparency. The ICC is arguably better resourced under its legal aid scheme. It is important to note that it also appears to exhibit a more robust system of engaging independent experts to reassess the functioning of the legal aid system.

Money flows into international courts legal aid schemes in many ways. These include mandatory contributions and voluntary contributions by states, corporations and individuals. Since the epoch making creation of the ICJ Trust Fund, institutional legal aid schemes have provided a practical means of overcoming financial obstacles to the settlement of disputes between states by judicial means. Eligibility and/ or disbursement of the leading funds are typically handled by special bodies of experts created for that purpose in the requisite international organisation in which the court is based. ${ }^{184}$ It is especially necessary for international courts that they develop clear and widely accessible policy directives that may provide effective guidance in relation to eligibility for use of their funds.

One of the most progressive aspects of international legal aid is the assistance given to victims to attend proceedings in courts that are far from the scenes of the violence they suffered and often in foreign lands. For example, the majority of witnesses who appeared before the ICTY were people who survived serious crimes or who witnessed the atrocities first hand. In some cases their family members were victims of war crimes. The Rome Statute of the ICC also grants victims unprecedented rights to appear at trials. Many of such victims still suffer physical and psychological trauma from the horror that they lived through. Therefore, it is good international policy to sustain and in fact increase survivor traffic to appear before international courts. As a

\footnotetext{
${ }^{184}$ Example here is the ICJ Trust funds panel of experts that evaluates applications The Terms of Reference, Guidelines and Rules are annexed to the report: Secretary-General's Trust Fund to Assist States in the Settlement of Disputes through the International Court of Justice: Report of the Secretary-General (A/ 47/444 of 7 October 1992).
} 
matter of fact it is good international policy to widen the scope of such aid to public international law cases as well. Thus, there may be a need for aid to be given to affected communities to be able to appear before international court and tribunals in relation to environmental matters. Whether a dam should be built or not may require the appearance of indigent communities or their representatives as amici curiae during the conduct of the case.

The international courts at The Hague are set to continue dispensing justice that have effects on the lives of peoples in far flung places in Africa, Asia and Latin America. It is important that the justice they deliver must be seen to be done directly by representatives of communities and groups. Thus, before straddling communities are split into different countries in foreign trials, it may make a difference to the affected population to be given an opportunity to at least attend the proceedings directly as observers of the process or to address the court. Unfortunately there is nothing in the rules of the use of the Trust Fund of the ICJ and the requisite PCA or ITLOS provisions that specifically allows this kind of use.

A further strategy to be recommended is that of reduction of costs of litigation in international proceedings. Bringing down costs of proceedings in international courts as a general policy may be seen as a good thing in and of itself. One way of reducing costs which has been suggested with regularity over the years for international courts such as the ICJ is to streamline their various rules of procedures and to limit the size of written pleadings and to keep them within reasonably clear limits especially as regards bulk and complexity. ${ }^{185}$ Apart from saving costs, this would facilitate a somewhat more rapid assimilation of the essential data on the part of both judges of the Court and counsel on the other side - therefore saving time which is especially advantageous for developing states. ${ }^{186}$

The fees of counsel and other experts that appear in international proceedings is certainly one of the factors that must be mentioned in any discussion about reduction of costs for impecunious states, individuals and peoples. It is not beyond contemplation that for many international lawyers, personal monetary aggrandisement does take a secondary place to their calling as officers in the temple of global justice. It is in this vein that Taslim Elias implored agents, counsel and

\footnotetext{
185 Max Planck Inst., supra note 16 at 29, 30, 160, 301.

186 Oduntan, supra note 39 at $266-268$.
} 
advocates of parties to disputes before the World Court 'to enact a selfdenying ordinance so that fees charged for service rendered to relatively impecunious clients or in respect of disputes not involving complicated commercial and industrial enterprises. ${ }^{187}$ We recommend this exhortation to international courts and tribunals in contemporary times.

It is important that in rendering help to indigent parties, domestic courts must avoid all appearances of compromising neutrality and impartiality. This recommendation will also avail international courts. We do not accept as reasonable the conclusions reached by other writers whose calculation is that legal aid unambiguously decreases the average success probability of a developing state as complainant presumably because it encourages an increase in filed complaints. Such allegations are unconvincing and unproven.

Open Access This article is distributed under the terms of the Creative Commons Attribution 4.0 International License (http://creativecommons.org/licenses/by/4.0/), which permits unrestricted use, distribution, and reproduction in any medium, provided you give appropriate credit to the original author(s) and the source, provide a link to the Creative Commons license, and indicate if changes were made.

Publisher's Note Springer Nature remains neutral with regard to jurisdictional claims in published maps and institutional affiliations.

${ }^{187}$ Max Planck Inst, supra note 16 at 30. 